\title{
ŚWIETLISTA DĄBROWA POTENTILLO ALBAE-QUERCETUM LIBBERT 1933 NOM. INVERS. W ŚRODKOWEJ CZĘŚCI WYŻYNY KRAKOWSKO-CZĘSTOCHOWSKIEJ
}

\author{
ANDRZEJ BRZEG ${ }^{1}$, STANISŁAW WIKA² \\ ${ }^{1}$ Zakład Ekologii Roślin i Ochrony Środowiska, Wydział Biologii, \\ Uniwersytet im. Adama Mickiewicza w Poznaniu, ul. Umultowska 89, 61-614 Poznań \\ ${ }^{2}$ Katedra Ekologii, Wydział Biologii i Ochrony Środowiska, Uniwersytet Śląski, \\ ul. Bankowa 12B, 40-007 Katowice
}

\begin{abstract}
The paper presents the results of phytosociological research on the thermophilous oak forest Potentillo albae-Quercetum Libbert 1933 nom. invers., which has been carried out in the central part of the Kraków-Częstochowa Upland. The association, which has been stated in 7 localities, is a new type of forest vegetation in this region. On the basis of 35 relevés, made in 2001 following the Braun-Blanquet method, the only subassociation P.a.-Q. brachypodietosum pinnati has been distinguished. It has been divided into two variants: with Pleurozium schreberi (on acid sites), and with Asarum europaeum (on basic ones). The investigated phytocoenoses abound in floristic peculiarities, such as: Adenophora liliifolia, Bupleurum longifolium, Euphorbia angulata, Festuca amethystina ssp. ritschlii, Lilium martagon, Potentilla alba.
\end{abstract}

Keywords: phytosociology, thermophilous oak forest, new localities, Natura 2000 site, floristic peculiarities, Poland

\section{WSTĘP}

Zbiorowiska leśne Wyżyny Krakowsko-Częstochowskiej, nazywanej także Wyżyną Krakowsko-Wieluńską, Jurą Krakowsko-Częstochowską (Brzeg, Wika 2014 i cytowana tam literatura) albo ujmowanej jako część Wyżyny Śląsko-Krakowskiej (Kondracki 2008), uchodzą za generalnie dobrze rozpoznane (m.in. Medwecka-Kornaś 1952; Medwecka-Kornaś i Kornaś 1963; Olaczek 1965; Michalik 1972, 1980; Hereźniak 1975, 1993, 2002; Kurowski 1979; Kurzac 1984, 1986; Medwecka-Kornaś, Gawroński 1990; Bąba 2002; Matuszkiewicz J. M. 2005). W interesującej nas środkowej części tego regionu (ryc. 1) badania fitosocjologiczne nad lasami prowadzili botanicy z różnych polskich ośrodków naukowych, przede wszystkim katowickiego, krakowskiego i łódzkiego (Sokołowski 1928; Hereźniak i in. 1970; Celiński, Wika 1975, 1978; Michalik 1981; Wika 1983, 1986, 1987, 1989; Wika i in. 1984, 2000, 2007; Michalska-Hejduk 1998; Michalska-Hejduk i in. 1999; Wika, Barć 2011; Barć i in. 2015 i wiele innych prac). Do najbardziej rozpowszechnionych i zarazem silnie zróżnicowanych 
ekosystemów leśnych należą tam buczyny (w tym wapieniolubne storczykowe), grądy i bory sosnowe.

Podczas prowadzonych w ostatnich latach, szczegółowych i wymagających dokładnej penetracji terenowej, badań nad termofilnymi ziołoroślami okrajkowymi (Brzeg, Wika 2007, 2011, 2014) stwierdzono obecność, w większości drobnopowierzchniowych fitocenoz, reprezentujących niepodawane we wcześniejszej literaturze zespoły, takie jak: wyżynny jodłowy bór mieszany Abietetum albae (scharakteryzowany w obszernej monografii Barć i in. 2015), podgórska dąbrowa z trzęślicą trzcinowatą Molinio arundinaceae-Quercetum, a także - na większych powierzchniach - świetlista dąbrowa Potentillo albae-Quercetum. Ten ostatni zespół, reprezentujący kolejne priorytetowe siedlisko przyrodnicze w programie Natura 2000 (91I0; Matuszkiewicz W. i in. 2012; Rozporządzenie Ministra... 2013; Obwieszczenie Ministra... 2014), jest tematem niniejszego artykułu.

Podstawowym celem pracy jest przedstawienie aktualnej dokumentacji fitosocjologicznej dotyczącej obecności Potentillo albae-Quercetum na obszarze środkowej części Wyżyny Krakowsko-Częstochowskiej, a ponadto ukazanie lokalnego zróżnicowania tego zespołu, jego rozmieszczenia, stanu zachowania oraz roli w utrzymaniu populacji rzadkich i interesujących elementów flory.

\section{TEREN BADAŃ, MATERIAŁ I METODY}

Obszar studiów (ryc. 1) jest analogiczny jak w poprzednich pracach autorów (por. Wika 1986; Brzeg, Wika 2011, 2014; Barć i in. 2015). W opracowaniach tych zawarta jest też jego szczegółowa charakterystyka fizjograficzna, którą tu celowo pominięto.

Badania prowadzono w lipcu $2001 \mathrm{r}$. Na jednorodnych i reprezentatywnych dla rozleglejszych fitocenoz świetlistej dąbrowy powierzchniach, o minimalnym areale $200 \mathrm{~m}^{2}$ (wyjątkowo mniejszym), wykonano 35 zdjęć fitosocjologicznych, stosując metodę Braun-Blanqueta (Pawłowski 1972; Dzwonko 2007). Zdjęcia te porównano i zestawiono ostatecznie w dwóch tabelach analitycznych, wykorzystując program Excel 2007 z pakietu Microsoft Office. Każde zdjęcie w terenie lokalizowano za pomocą odbiornika GPS Garmin Oregon 400, notując współrzędne geograficzne i wyniesienie n.p.m. (por. zamieszczone dalej wykazy). Fizjonomię studiowanych płatów i obecność szczególnie interesujących gatunków roślin udokumentowano w formie fotografii.

Pozycję systematyczną i charakterystykę florystyczną Potentillo albae-Quercetum i wyższej rangi syntaksonów przyjęto za Ratyńską i in. (2010) oraz Matuszkiewiczem W. i in. (2012). Zastosowano koncepcję wewnętrznego zróżnicowania tego zespołu według prac Wojterskiej i Wiszniewskiej (1996), Brzega i Kasprowicza (2001), Wojterskiej i in. $(2001,2007)$ oraz Brzega i in. (2009). 


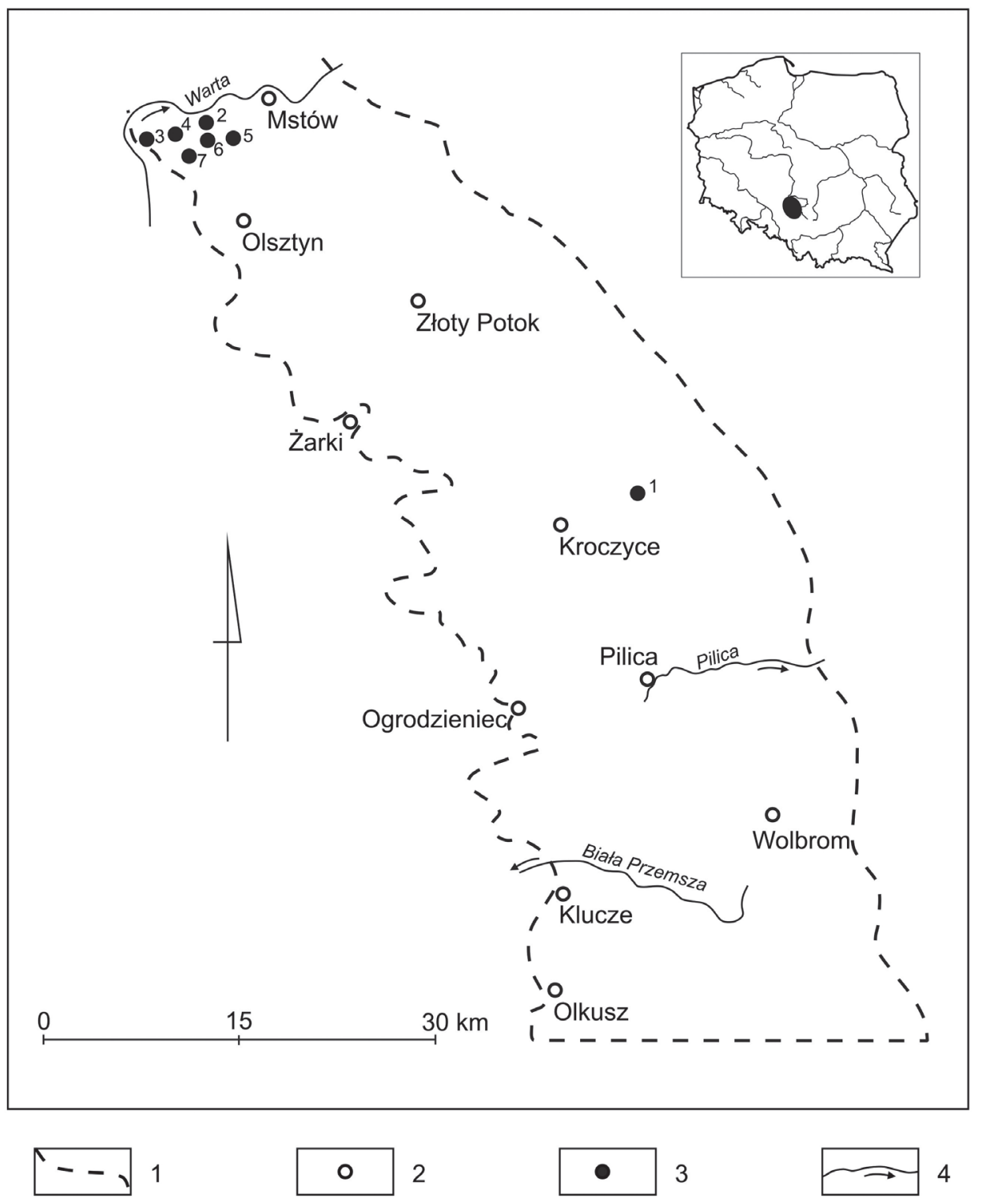

Ryc. 1. Rozmieszczenie stanowisk Potentillo albae-Quercetum na obszarze środkowej części Wyżyny Krakowsko-Częstochowskiej

1 - granica terenu badań, 2 - ważniejsze miejscowości, 3 - stanowiska zespołu, 4 - rzeki

Fig. 1. Distribution of localities of the Potentillo albae-Quercetum in the central part of the Kraków-Częstochowa Upland

1 - investigated area boundary, 2 - major towns and villages, 3 - localitization of the association patches, 4 - rivers 
Nomenklaturę taksonów roślin naczyniowych podano zasadniczo według Mirka i in. (2002), a mchów według Ochyry i in. (2003).

Lokalizacja zdjęć fitosocjologicznych z tabeli 1 - Location of relevés from Table 1 (P.a.-Q. brachypodietosum pinnati Pleurozium var.):

1(3) [N 50.58898 ${ }^{\circ}$ E $019.63887^{\circ} \pm 7$ m, 308 m n.p.m.]; 2(1) [N 50.58850 $\mathrm{E} 019.63659^{\circ} \pm 6 \mathrm{~m}$,

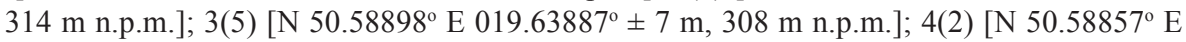
$019.63712^{\circ} \pm 10 \mathrm{~m}, 315 \mathrm{~m}$ n.p.m.]; 5(4) [N $50.58852^{\circ} \mathrm{E} 019.63802^{\circ} \pm 7 \mathrm{~m}, 312 \mathrm{~m} \mathrm{n.p.m.]}$; 6(6) $\left[\mathrm{N} 50.58770^{\circ} \mathrm{E} 019.63764^{\circ} \pm 13 \mathrm{~m}, 312 \mathrm{~m} \mathrm{n.p.m.}\right] ; 8(8)$ [N 50.58641 ${ }^{\circ}$ E $019.63868^{\circ} \pm$ 12 m, 312 m n.p.m.]: Lasy Pradelskie, na E od szosy nr 794 relacji Pradła-Biała Błotna; 7(7) [N 50.58810 ${ }^{\circ}$ E $019.63629^{\circ} \pm 8$ m, 313 m n.p.m.]: j.w., na W od szosy nr 794 - stanowisko 1 (por. ryc. 1);

9(31) [N 50.78728 ${ }^{\circ}$ E $019.24132^{\circ} \pm 8$ m, 303 m n.p.m.]; 10(33) [N 50.78602 ${ }^{\circ}$ E $019.24010^{\circ} \pm$ 9 m, 310 m n.p.m.]; 11(30) [N 50.78753 E 019.24160 \pm 10 m, 316 m n.p.m.]: Kusięta, gm. Olsztyn, w pobliżu skałek Psi Nos, południowe stoki - stanowisko 6;

12(27) [N 50.79070 E 019.24718 \pm 7 m, 311 m n.p.m.]: Srocko, gm. Mstów, na S od wsi, Skałki, w pobliżu Systemu Srockich Jaskiń - stanowisko 5.

Lokalizacja zdjęć fitosocjologicznych z tabeli 2 - Location of relevés from Table 2 (P.a.-Q. brachypodietosum pinnati Asarum var.):

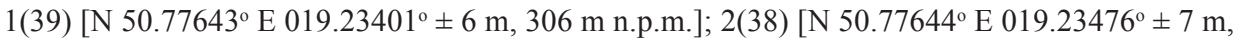
293 m n.p.m.]: Kusięta, gm. Olsztyn, rez. Zielona Góra, S obrzeża ostańca wapiennego, poniżej fitocenoz grądowych - stanowisko 7 (por. ryc. 1);

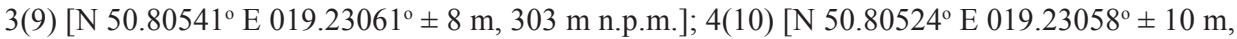

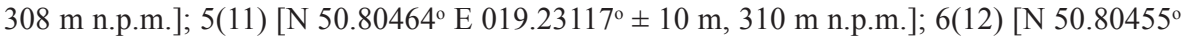
E $019.23116^{\circ} \pm 9$ m, 310 m n.p.m.]; 7(13) [N 50.80432 ${ }^{\circ}$ E 019.23147 \pm 7 m, 301 m n.p.m.];

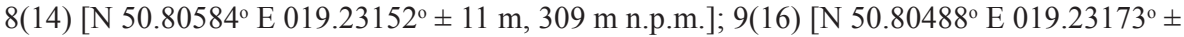
13 m, 305 m n.p.m.]: Srocko, gm. Mstów, ostaniec wapienny Liboradz - stanowisko 2;

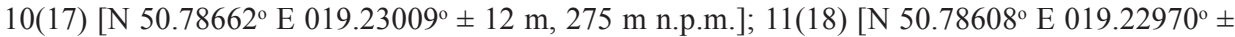
7 m, 272 m n.p.m.]; 12(19) [N 50.78667 E 019.23102 \pm 7 m, 284 m n.p.m.]: Częstochowa, na E od miasta, ostaniec wapienny Młodosowa - stanowisko 3;

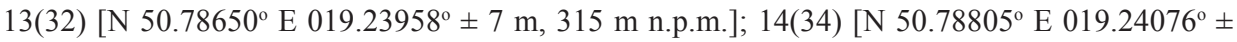
7 m, 320 m n.p.m.]: Kusięta, gm. Olsztyn, część przygraniowa skałek Psi Nos, w pobliżu drogi leśnej prowadzącej do wsi Srocko - stanowisko 6;

$15(20)\left[\mathrm{N} 50.78661^{\circ} \mathrm{E} 019.23139^{\circ} \pm 6 \mathrm{~m}, 276 \mathrm{~m} \mathrm{n.p.m.]} ; 16(21)\left[\mathrm{N} 50.78321^{\circ} \mathrm{E} 019.21128^{\circ}\right.\right.$ $\pm 9 \mathrm{~m}, 266 \mathrm{~m}$ n.p.m.]; 17(22) [N 50.78344 $\mathrm{E} 019.21089^{\circ} \pm 9 \mathrm{~m}, 251 \mathrm{~m}$ n.p.m.]; 18(23) [N 50.78312 ${ }^{\circ} \mathrm{E} 019.21009^{\circ} \pm 11 \mathrm{~m}, 267 \mathrm{~m}$ n.p.m.]; 19(24) [N 50.78271 ${ }^{\circ} \mathrm{E} 019.20989^{\circ} \pm 7 \mathrm{~m}$,

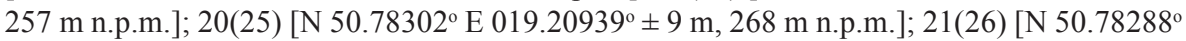
E $019.20937^{\circ} \pm 10$ m, 271 m n.p.m.]: Kusięta, gm. Olsztyn, ostaniec wapienny Dębowa Góra na $\mathrm{N}$ od leśniczówki - stanowisko 4;

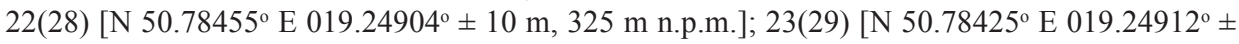
$9 \mathrm{~m}, 325 \mathrm{~m}$ n.p.m.]: Srocko, gm. Mstów, na S od wsi, północne skłony grzbietu wzniesienia 329 m n.p.m., na SW od Systemu Srockich Jaskiń - stanowisko 5.

W artykule (w tekście lub tabelach) zastosowano, poza ogólnie znanymi, następujące skróty: (A) - Ch. Artemisietea vulgaris; C. - stopień stałości (constancy degree); (CU) - Ch. CallunoUlicetea; (F) - takson Ch. w ramach danej formacji (Ch. within forest formation); (FB) - Ch. Festuco-Brometea; gm. - gmina (commune within administration division); (MA) - Ch. Molinio-Ar- 
rhenatheretea; (QF) - Ch. Querco-Fagetea); rez. - rezerwat (nature reserve); (TG) - Ch. TrifolioGeranietea sanguinei; (VP) - Ch. Vaccinio-Piceetea.

\section{WYNIKI}

\section{Rozmieszczenie i warunki występowania Potentillo albae-Quercetum na terenie badań}

Obecność fitocenoz świetlistej dąbrowy na terenie środkowej części Wyżyny Krakowsko-Częstochowskiej stwierdzono tylko na siedmiu stanowiskach. Sześć z nich koncentruje się w północno-zachodniej części tego obszaru, tj. między Częstochową, Mstowem i Olsztynem, głównie w granicach Ostoi Olsztyńsko-Mirowskiej PLH 240015 (por. ryc. 1 oraz mapa Czechowskiego i in. b.d.). Osobne stanowisko zlokalizowano między Pradłami a Białą Błotną na północny wschód od Kroczyc. Szczegółowy wykaz miejsc wykonywania zdjęć fitosocjologicznych zamieszczono w poprzednim rozdziale.

Na poszczególnych stanowiskach Potentillo albae-Quercetum zajmuje areał rzędu od około 1 ha (rez. Zielona Góra) do ponad 5 ha, tworząc miejscami wielkopowierzchniowe płaty. Fitocenozy tego typu lokują się zwykle w podszczytowych partiach wzgórz wapiennych, przeważnie na niezbyt nachylonych stokach o różnych ekspozycjach, w przedziale wysokości od $251 \mathrm{~m}$ n.p.m. do 325 m n.p.m. (por. tab. 1 i 2). Zajmują gleby typu rędzin, rzadziej pararędzin niecałkowitych, wytworzonych z piasków gliniastych pylastych szkieletowych lub utworów lessopodobnych, zalegających płytko na skałach wapiennych. $\mathrm{W}$ terenie najczęściej sąsiadują z płatami grądu subkontynentalnego Tilio-Carpinetum.

\section{Struktura i skład florystyczny zespołu}

Drzewostany badanego zespołu są przeważnie dwuwarstwowe ze słabo rozwiniętym (zwarcie od 5-20\%, średnio 8\%) dolnym piętrem, znacznie rzadziej jednowarstwowe. W płatach zbliżonych do naturalnych górne piętro, osiągające wysokość 15-25 m i zwarcie 45\% do niekiedy 80\% (średnio 68\%), tworzą dęby, najczęściej Quercus petraea (ryc. 2), nierzadko z domieszką Betula pendula i/lub Pinus sylvestris, sporadycznie innych gatunków drzew. Często są to starodrzewy, w których dęby osiągają średnicę nawet $50 \mathrm{~cm}$ w pierśnicy. W fitocenozach zniekształconych przez gospodarkę leśną, obecnych głównie na stanowisku koło Białej Błotnej (ryc. 3), w piętrze tym panuje nasadzona sosna o maksymalnej pierśnicy od $30 \mathrm{~cm}$ do $50 \mathrm{~cm}$. W dolnym piętrze, obok młodszych okazów wyżej wymienionych gatunków drzew, niezbyt licznie pojawiają 
się gdzieniegdzie Carpinus betulus, Fagus sylvatica i Tilia cordata, a lokalnie w skład tego piętra wchodzą też wybujałe okazy Corylus avellana (tab. 1 i 2).

Warstwa krzewów jest zawsze obecna, osiągając zwarcie od 5\% do nawet 30\% (średnio 19\%). Obok podrostu drzew głównymi jej składnikami są przeważnie Corylus avellana i Frangula alnus. Do częstych elementów tej warstwy należą też: Cornus sanguinea, Crataegus rhipidophylla, Lonicera xylosteum i Sorbus aucuparia, rzadziej pojawiają się m.in: Euonymus verrucosus, Juniperus communis, Prunus spinosa, Pyrus pyraster i Rhamnus cathartica.

Warstwa zielna ma charakter ziołoroślowo-trawiasty i osiąga pokrycie 70$90 \%$ (sporadycznie nawet 100\%, średnio 82\%). Do jej najważniejszych składników, rosnących bardzo często i zwykle licznie, należą: Ajuga reptans, Brachypodium pinnatum (ryc. 3), Campanula persicifolia, Carex digitata, C. montana, Clinopodium vulgare, Convallaria majalis (ryc. 2 i 6), Cruciata glabra, Fragaria vesca, Galium schultesii, Hepatica nobilis, Melica nutans, Melittis melissophyllum, Pteridium aquilinum i Viola riviniana.

Przyziemna warstwa mszysta, niemal zawsze obecna, pokrywa jednak niewielkie powierzchnie (maksymalnie 15\%, średnio 5\%). Jej najczęstszymi gatunkami są: Atrichum undulatum, Brachytheciastrum velutinum, Brachythecium rutabulum i Plagiomnium affine.

Badane fitocenozy Potentillo albae-Quercetum są bogate florystycznie. W poszczególnych zdjęciach fitosocjologicznych notowano od 56 do 86 taksonów roślin (średnio 71). Pod względem syntaksonomicznym jest najmocniej reprezentowana w zebranym materiale klasa Querco-Fagetea s.l., istotny jest też udział gatunków z klas: Trifolio-Geranietea sanguinei, Molinio-Arrhenatheretea i Festuco-Brometea. Najbogatszymi w gatunki rodzajami były: Rubus, Hieracium, Campanula i Galium (tab. 3). W tabeli 3 zamieszczono też, w syntetycznej formie, udział gatunków diagnostycznych dla zespołu, z których na obszarze badań najczęściej występowały Carex montana i Ranunculus polyanthemos, rzadziej m.in. Betonica officinalis, Galium boreale i Vicia casssubi$c a$, a Potentilla alba, a także Festuca amethystina ssp. ritschlii (ryc. 4) zostały znalezione tylko na pojedynczych stanowiskach. Dla diagnozy zespołu i rozpoznawania jego płatów w terenie ważny jest także grupowy udział gatunków charakterystycznych i wyróżniających rzędu Quercetalia pubescenti-petraeae (tab. 1 i 2 ).

\section{Zróżnicowanie zespołu}

Z przeprowadzonej analizy tabelarycznej i porównawczej zebranego materiału zdjęciowego wynika, że wszystkie udokumentowane w środkowej części Wyżyny Krakowsko-Częstochowskiej fitocenozy świetlistej dąbrowy reprezentują, według koncepcji Wojterskiej i Wiszniewskiej (1996), Brzega i Kasprowicza 


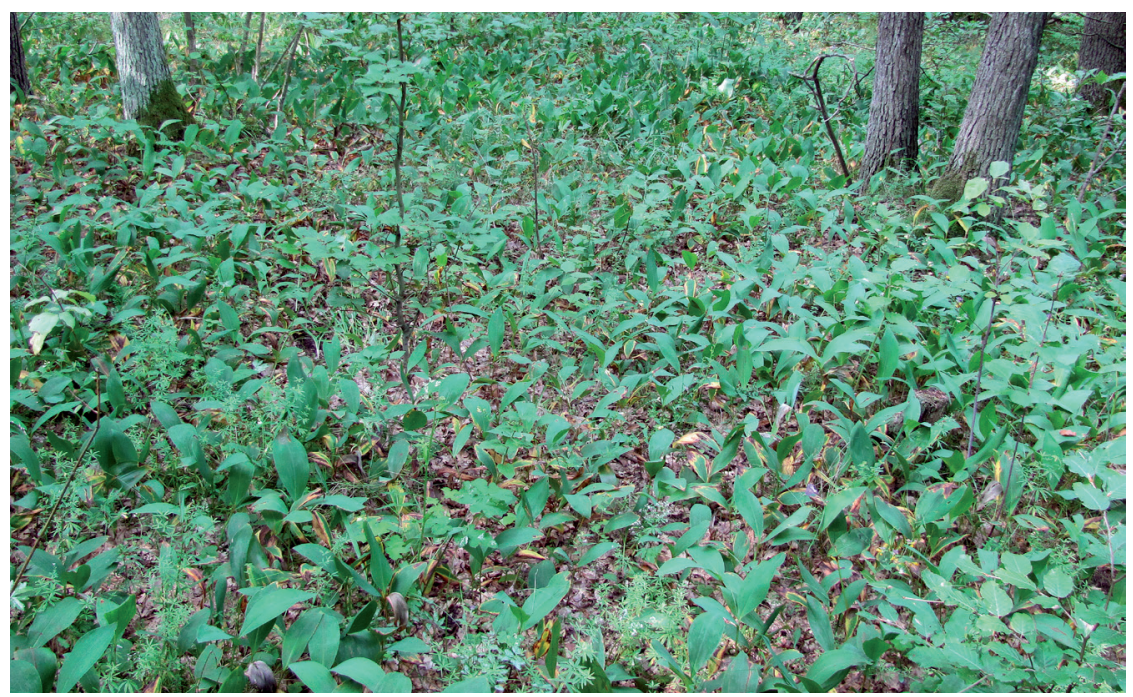

Ryc. 2. Płat Potentillo albae-Quercetum z drzewostanem dębowym i masowym udziałem Convallaria majalis w runie na górze Liboradz koło Srocka. Fot. S. Wika, 6.08.2011 r.

Fig. 2. A patch of the Potentillo albae-Quercetum with oak stand and a dominant share of Convallaria majalis in herb layer on Liboradz hill near Srocko. Phot. S. Wika, 6.08.2011

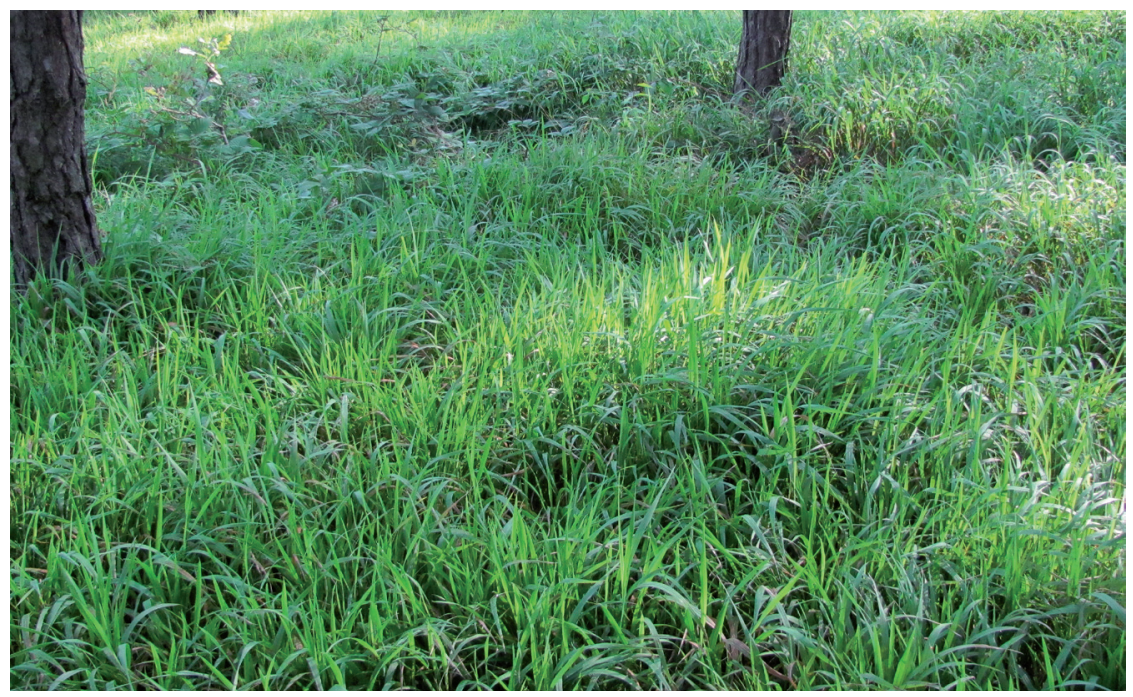

Ryc. 3. Zniekształcony płat Potentillo albae-Quercetum z dominacją nasadzonej Pinus sylvestris $\mathrm{w}$ drzewostanie i Brachypodium pinnatum $\mathrm{w}$ runie koło Białej Błotnej.

Fot. S. Wika, 5.08.2011 r.

Fig. 3. Distorted patch of the Potentillo albae-Quercetum with the stand dominated by planted Pinus sylvestris and Brachypodium pinnatum in herb layer near Biała Błotna.

Phot. S. Wika, 5.08.2011 


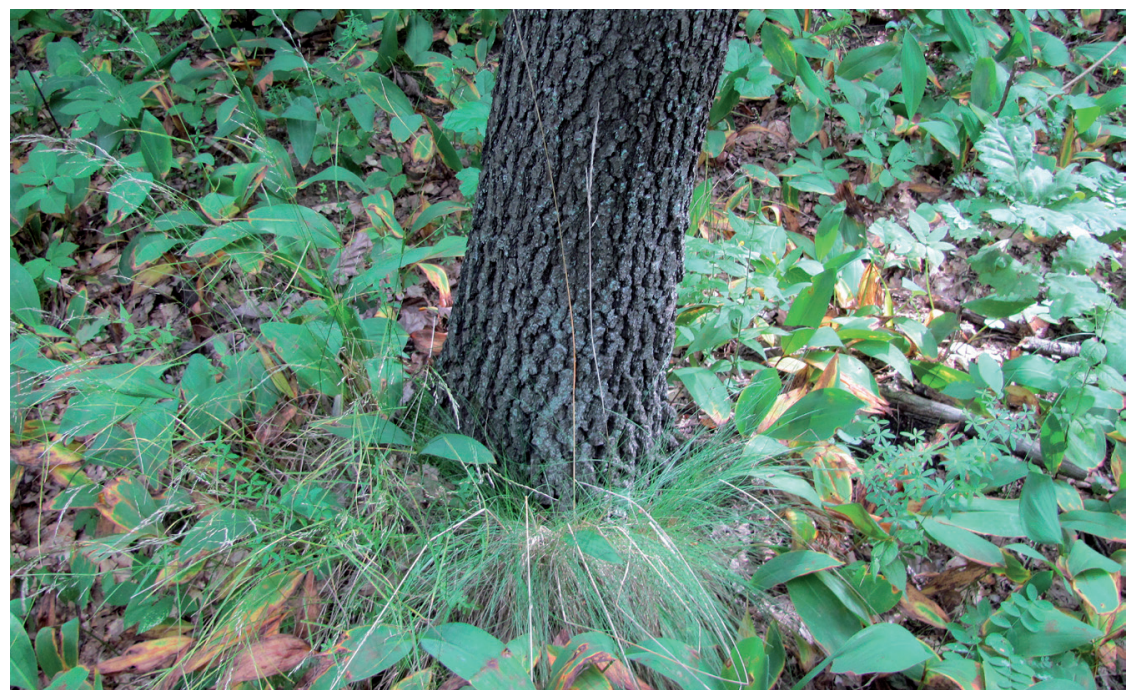

Ryc. 4. Kępka Festuca amethystina ssp. ritschlii w płacie Potentillo albae-Quercetum na górze Liboradz koło Srocka. Fot. S. Wika, 6.08.2011 r.

Fig. 4. A clump of Festuca amethystina ssp. ritschlii in a patch of the Potentillo albae-Quercetum on Liboradz hill near Srocko. Phot. S. Wika, 6.08.2011

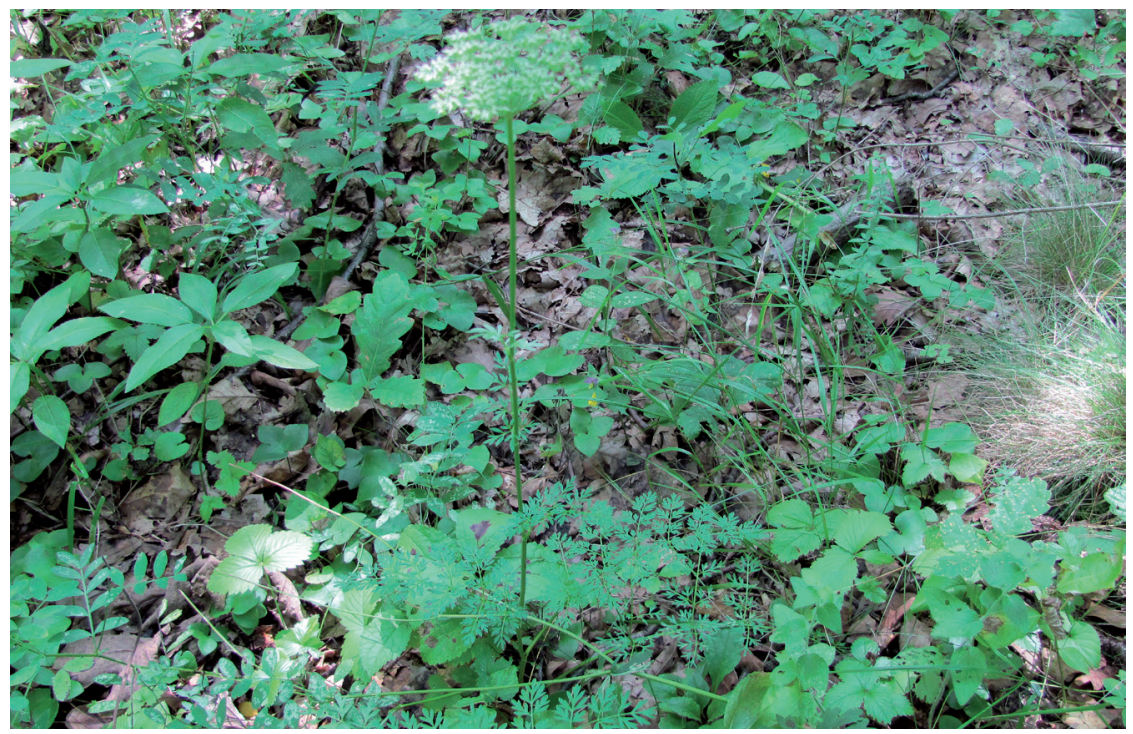

Ryc. 5. Fragment runa fitocenozy Potentillo albae-Quercetum brachypodietosum pinnati w wariancie z Asarum z udziałem wilgociolubnego Selinum carvifolia na górze Psi Nos koło Kusiąt. Fot. S. Wika, 9.08.2011 r.

Fig. 5. A fragment of herb layer in a phytocoenosis of the Potentillo albae-Quercetum brachypodietosum pinnati Asarum var. with a share of hygrophilous Selinum carvifolia on Psi Nos hill near Kusięta. Phot. S. Wika, 9.08.2011 
Tabela 1 - Table 1

Potentillo albae-Quercetum Libbert 1933 nom. invers. brachypodietosum pinnati Pleurozium var.

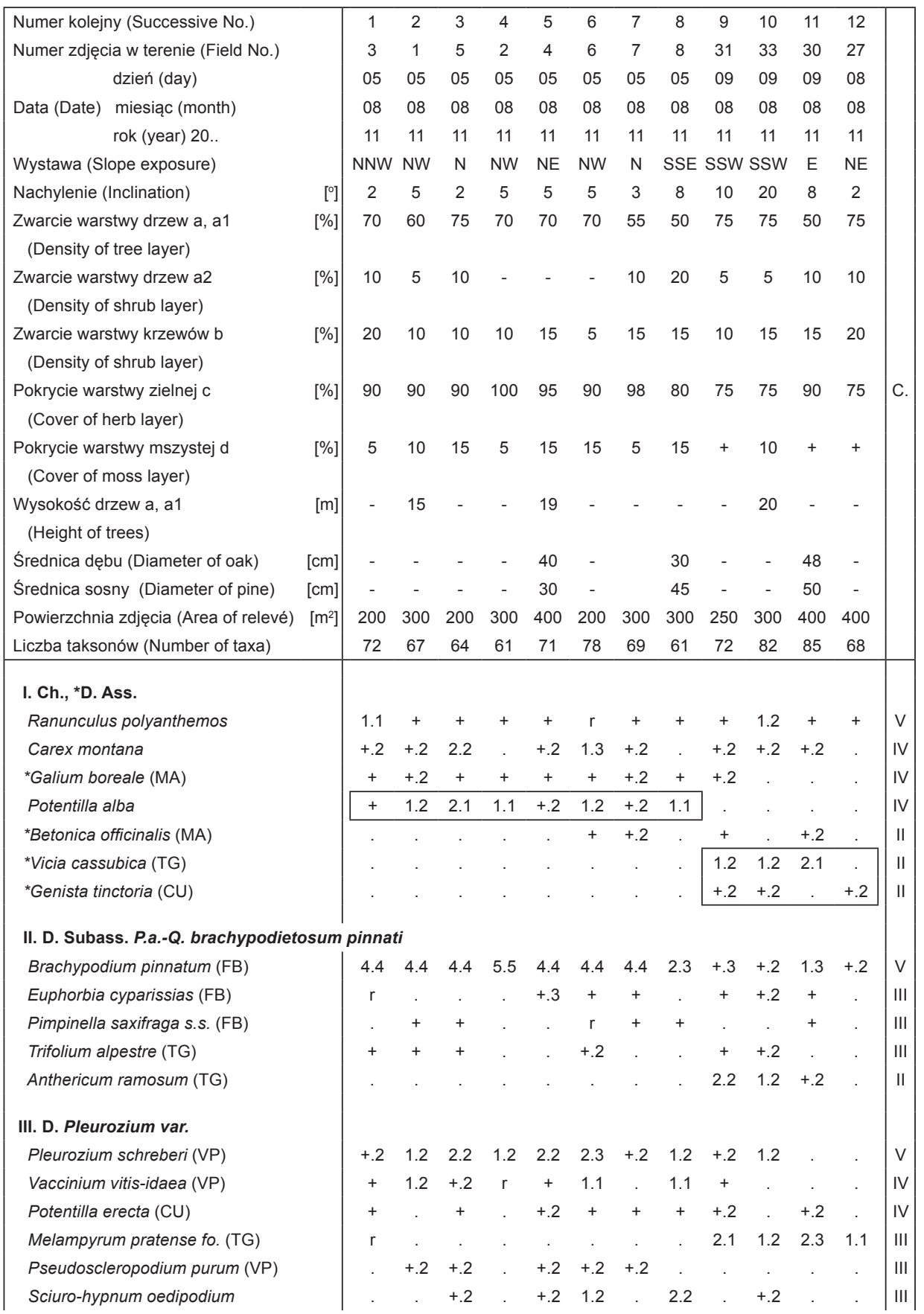


Danthonia decumbens (CU)
Orthilia secunda (VP)
Trientalis europaea (VP)

IV. Ch. Quercetalia pubescenti-petraeae

Clinopodium vulgare $(F)$

Campanula persicifolia

Euphorbia angulata $(\mathrm{F})$

Viola collina $(\mathrm{F})$

Polygonatum odoratum (F)

Lathyrus niger

Melittis melissophyllum

Primula veris fo.

Hypericum montanum

\section{Ch. Querco-Fagetea}

Carpinus betulus a2

Carpinus betulus b

Carpinus betulus c

Fagus sylvatica a2

Fagus sylvatica b

Fagus sylvatica c

Cerasus avium a2

Cerasus avium b

Cerasus avium c

Tilia cordata a, a2

Tilia cordata b

Tilia cordata c

Corylus avellana b

Corylus avellana c

Acer platanoides b/c

Euonymus verrucosus $\mathrm{c}$

Melica nutans

Viola riviniana

Ajuga reptans

Anemone nemorosa

Hepatica nobilis

Carex digitata

Atrichum undulatum

Brachypodium sylvaticum

Sanicula europaea

Eurhynchium angustirete

Galium schultesii

Mercurialis perennis

\section{Ch. Vaccinio-Piceetea}

Pinus sylvestris a, a1

Pinus sylvestris a2

Pinus sylvestri sb/c

Vaccinium myrtillus

Rubus saxatilis

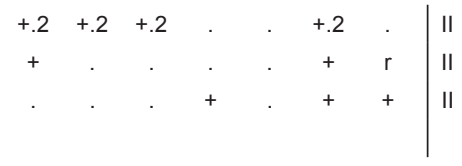

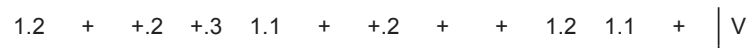

$$
\begin{aligned}
& 1.2++.2+++++21.2++.2 \mathrm{~V} \\
& +.22 .1+2.11 .1++.21 .1 . . \quad . \quad \text { IV }
\end{aligned}
$$

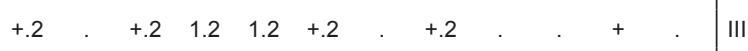

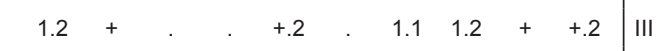

$$
\begin{aligned}
& \begin{array}{llllll|l}
+.2 & + & +.2 & 1.2 & 1.1 & 1.2 & \text { III }
\end{array} \\
& \begin{array}{ccccccccccc|c|c}
\cdot & \cdot & \cdot & \mathrm{r} & \cdot & \cdot & \cdot & 1.1 & 1.1 & 1.1 & \mathrm{r} & \mathrm{III} \\
+ & \cdot & +.2 & \cdot & + & \cdot & \cdot & \cdot & \cdot & \cdot & \cdot & \mathrm{II}
\end{array} \\
& \text {. . . . . . . . } r \text {. } \\
& +\quad 1.2 \quad . \quad 1.1+1.2 . \quad . \quad \text {. } \quad \text { III } \\
& \begin{array}{cccccccccccc|c}
+ & \cdot & 1.2 & \cdot & \cdot & 1.1 & + & 1.2 & \cdot & \cdot & \cdot & \cdot & \\
2.2 & + & 1.2 & \cdot & 2.3 & \cdot & 1.2 & 2.2 & + & \cdot & + & \cdot \\
+ & \cdot & + & + & + & \cdot & + & 1.1 & + & + & + & + & \mathrm{V}
\end{array}
\end{aligned}
$$

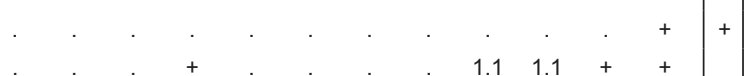

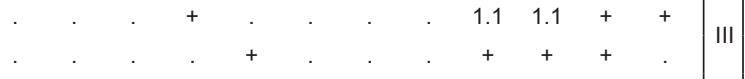

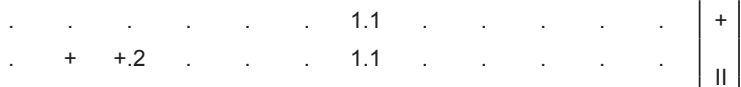

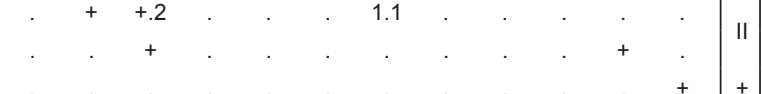

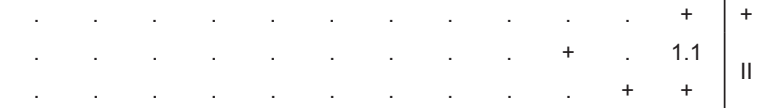

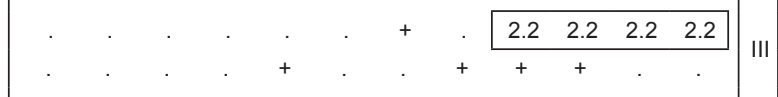

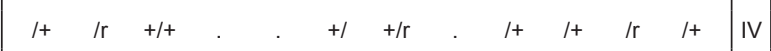

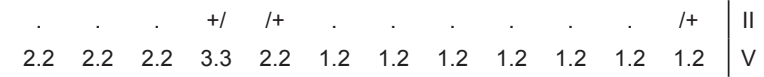

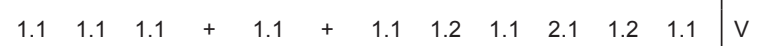

$$
\begin{aligned}
& +.2++.2+\quad+.2+.2 \quad+\quad \begin{array}{lllll}
1.2 & 1.2 & 1.2 & 1.2 & \mathrm{~V}
\end{array} \\
& +++1.1+1.2+++2.1 .6 \mathrm{~V} \\
& \begin{array}{llllllllll}
2.2 & 2.2 & 2.2 & 3.3 & 2.3 & 2.2 & 1.2 & 1.2+\ldots & +
\end{array} \\
& \begin{array}{lllllllllllll} 
& 1.2 & 1.2 & +.2 & +.2 & 1.2 & 1.2 & \cdot .2 & +.2 & \cdot .2 & 1.2 & \cdot 1.2 & \text { IV }
\end{array}
\end{aligned}
$$

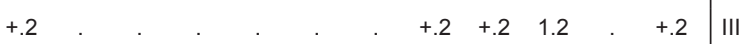

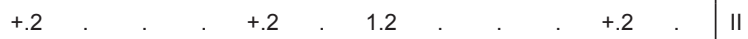

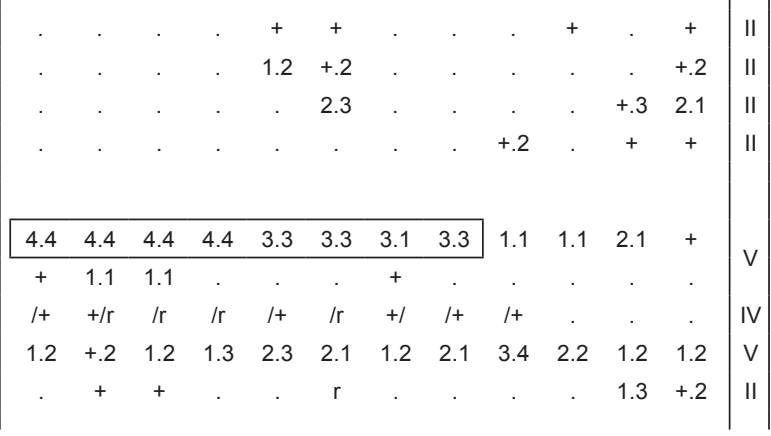


VII. Ch. Trifolio-Geranietea sanguinei

Fragaria vesca

Galium album var. dumetorum

Coronilla varia

Hypericum perforatum

Astragalus glycyphyllos

Knautia arvensis fo.

Chamaecytisus ruthenicus

Trifolium medium

Poa angustifolia var. setacea

\section{Ch. Molinio-Arrhenatheretea}

Heracleum sphondylium s.s.

Veronica chamaedrys s.s.

Vicia cracca

Taraxacum officinale agg.

Festuca rubra s.s.

Prunella vulgaris

\section{Ch. Calluno-Ulicetea}

Solidago virgaurea s.s.

Pohlia nutans

Veronica officinalis

Agrostis capillaris

Carex pilulifera

\section{Ch. Rhamno-Prunetea}

Frangula alnus b

Frangula alnus c

Crataegus rhipidophylla s.s. a2

Crataegus rhipidophylla s.s. b

Crataegus rhipidophylla s.s. c

Viburnum opulus b

Viburnum opulus c

Pyrus pyraster b/c

Populus tremula a,a2

Populus tremula b

Populus tremula c

Prunus spinosa b

Prunus spinosa c

Cornus sanguinea $\mathrm{b}$

Cornus sanguinea c

Rhamnus catharticusb/c

Rosa canina b/c

Crataegus monogyna b/c

\section{Ch. Artemisietea vulgaris}

Rubus caesius

XII. Inne (Others)

Quercus petraea a, a1

Quercus petraea a2

Quercus petraea b

Quercus petraea c

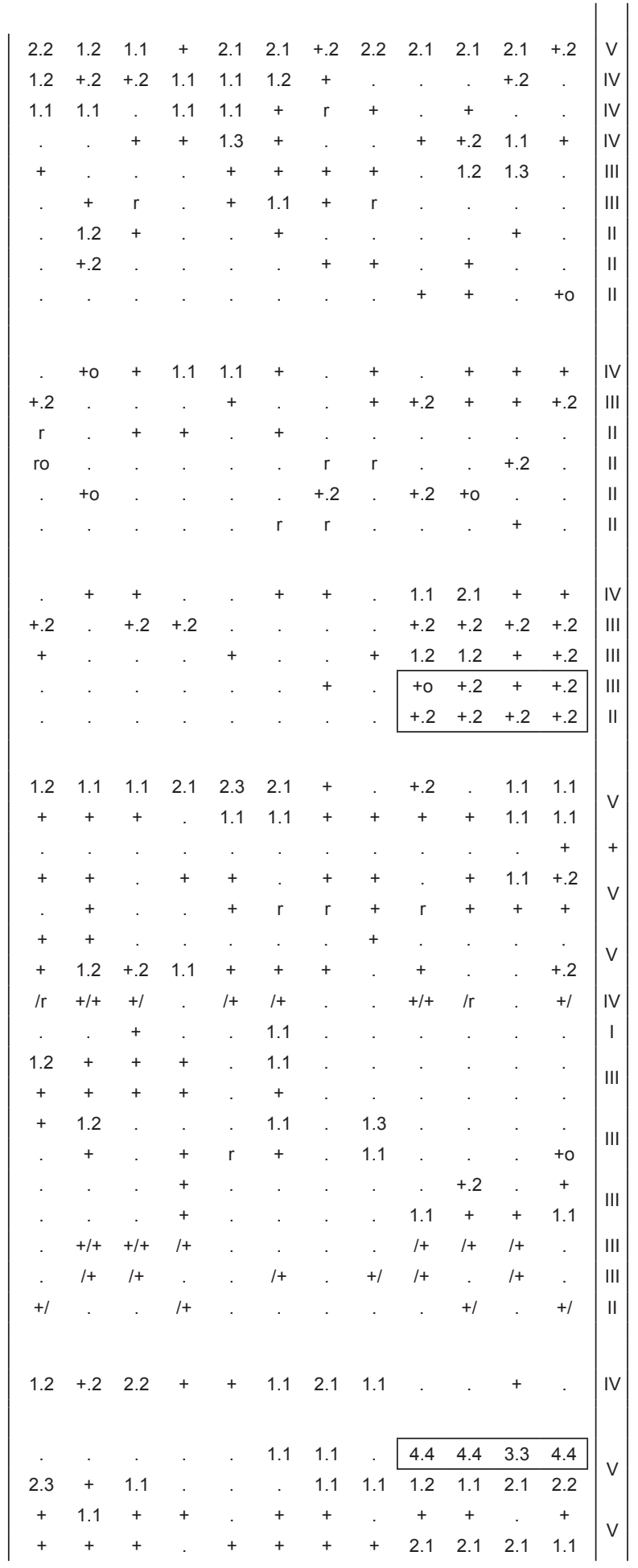




\begin{tabular}{|c|c|c|c|c|c|c|c|c|c|c|c|c|}
\hline Quercus robur a,a1 & . & . & . & 1.1 & 2.3 & 1.1 & . & 2.1 & . & . & 1.1 & . \\
\hline Quercus robur a2 & + & . & + & . & . & . & + & 2.1 & . & . & . & . \\
\hline Quercus robur b & + & 1.1 & 1.1 & + & 1.1 & . & 1.1 & . & . & . & . & . \\
\hline Quercus robur c & + & + & 1.1 & 1.1 & + & + & + & + & . & . & + & . \\
\hline Betula pendula a,a1 & . & . & + & . & . & 1.1 & 1.2 & . & . & . & . & . \\
\hline Betula pendula a2 & . & + & + & . & . & . & + & . & . & . & . & . \\
\hline Betula pendula b & 1.2 & +.2 & + & . & + & + & 1.2 & + & . & . & . & . \\
\hline Betula pendula c & . & + & . & + & + & . & + & + & . & . & . & . \\
\hline Sorbus aucuparia s.s. a2 & . & . & + & . & . & . & . & . & . & . & . & . \\
\hline Sorbus aucuparia s.s. c & 1+ & +1 & +1 & +1 & +1 & $+/+$ & . & $+/+$ & +1 & +1 & +1 & +1 \\
\hline Juniperus communis s.s. b/c & +1 & $+/+$ & $+/+$ & $+/+$ & $+/+$ & $1+$ & +1 & $1+$ & . & . & . & +1 \\
\hline Cruciata glabra & 1.2 & 1.1 & 1.1 & 1.1 & 1.1 & 1.1 & 1.1 & 2.1 & 1.1 & 1.2 & 2.1 & 1.1 \\
\hline Pteridium aquilinum & + & 2.2 & 2.2 & 1.3 & + & 1.1 & +.2 & + & 1.1 & 1.2 & 1.3 & 3.1 \\
\hline Deschampsia flexuosa & 1.2 & +.2 & +.2 & +.2 & 1.2 & +.2 & +.2 & 2.2 & 1.2 & 1.2 & 1.2 & +.2 \\
\hline Rubus $\times$ corylifolius & 2.2 & 2.2 & 1.2 & 1.1 & 2.1 & 1.1 & 2.2 & 1.1 & + & + & + & . \\
\hline Brachythecium rutabulum & 1.2 & +.2 & +.2 & 1.2 & 1.2 & +.2 & +.2 & 1.2 & . & +.2 & +.2 & +.2 \\
\hline Plagiomnium affine & +.2 & . & 1.2 & +.2 & 1.2 & 1.2 & 1.2 & 1.2 & . & 1.2 & +.2 & +.2 \\
\hline Maianthemum bifolium & 1.2 & +.2 & . & 2.1 & + & . & + & . & +.2 & +.2 & . & + \\
\hline Convallaria majalis & 1.2 & . & . & . & 1.2 & 1.1 & +.2 & 3.4 & 2.3 & 3.3 & 3.4 & 4.4 \\
\hline Rubus plicatus & . & . & + & + & 1.1 & . & 1.2 & + & +.2 & . & + & +o \\
\hline Hieracium murorum & +.2 & . & + & . & + & + & . & 2.1 & +.2 & . & + & . \\
\hline Luzula pilosa & +.2 & . & + & . & . & . & . & +.2 & +.2 & 1.2 & +.2 & +.2 \\
\hline Festuca ovina s.s. & . & +.2 & . & . & . & +.2 & . & +.2 & 1.2 & 2.2 & +.2 & . \\
\hline Rubus idaeus & +.2 & . & . & + & + & + & . & . & +o & . & . & . \\
\hline Rubus gracilis & 1.2 & . & +.2 & + & + & . & 1.2 & . & . & . & . & . \\
\hline Thuidium philibertii & . & 1.2 & 1.2 & . & 1.2 & +.2 & . & . & . & . & . & . \\
\hline Rubus pedemontanus & 1.2 & +.2 & . & . & . & . & +.2 & . & . & . & . & . \\
\hline Quercus rubra c & . & . & $\mathrm{r}$ & . & $\mathrm{r}$ & . & . & + & . & . & . & . \\
\hline Calamagrostis epigejos & 1.2 & . & . & +.2 & . & . & + & . & . & . & +.2 & . \\
\hline Hieracium sabaudum & . & . & . & . & + & . & . & . & $r$ & + & + & + \\
\hline Polytrichastrum formosum & . & . & . & . & . & . & . & . & +.2 & 2.2 & +.2 & +.2 \\
\hline Calamagrostis arundinacea & . & . & . & . & . & . & . & . & +.2 & +.2 & +.2 & +.2 \\
\hline Hieracium lachenalii & . & . & . & . & . & . & . & . & +.2 & + & + & +.2 \\
\hline
\end{tabular}

Taksony sporadyczne z tabeli 1 (Sporadic taxa from Table 1): V.: Campanula trachelium 9(r), 11(+); Daphne mezereum c 12(r); Epipactis helleborine 6(r); Festuca gigantea 11(+); Fraxinus excelsior c 4(r); Galium odoratum 12(+); Lonicera xylosteum b/c 11(+/+), 12(+/); Malus sylvestris c 1(r), 10(r); Poa nemoralis s.s. 10(+); Ribes spicatum c 4(+), 9(+); Ribes uva-crispa c 1(+); Scrophularia nodosa 5(r); VI.: Leucobryum glaucum 10(+); Pyrola minor 6(+), 10(+); VII.: Agrimonia procera 7(+); Galium verum fo. 2(r), 4(+); Melampyrum nemorosum 10(+); Peucedanum cervaria 4(+); Peucedanum oreoselinum 12(+); Sedum maximum fo. 11(+); Senecio jacobaea fo. 11(+); Silene nutans 10(+); Vicia sepium fo. 4(+); VIII.: Achillea millefolium 6(+); Briza media 10(+); Dactylis glomerata s.s. 9(+); Deschampsia caespitosa 5(+), 7(+); Leontodon hispidus ssp. danubialis 1(+); Lotus corniculatus 2(r); Rhytidiadelphus squarrosus 8(+); Rumex acetosa 1(r); IX.: Genista germanica 10(+); Hieracium pilosella 10(+); Luzula campestris 11(r); Polytrichum juniperinum 1(+); X.: Berberis vulgaris b 5(+), 7(+); Rosa dumalis b 2(+); Rosa rubiginosa b 1(+); XI.: Cirsium arvense 1(+), 7(+); Epilobium montanum 11(+), 12(r); Geum urbanum 1(+), 8(r); Mycelis muralis 9(+), 11(+); Torilis japonica 11(+); XII.: Alchemilla glaucescens (FB) 7(+); Anthoxanthum odoratum 10(+), 11(+); Brachytheciastrum velutinum 1(+), 8(+); Calliergonella cuspidata 6(+); Campanula glomerata (FB) 6(r); Campanula rotundifolia 10(+); Carex flacca (FB) 7(+); Cirsium vulgare var. sylvaticum 7(+); Dicranella heteromalla 9(+); Gnaphalium sylvaticum 10(r); Helianthemum nummularium ssp. obscurum (FB) 2(+); Homalothecium lutescens (FB) 2(+), 8(+); Hypnum cupressiforme s.s. 10(+); Hypnum cupressiforme var. lacunosum 2(+); Juglans regia c 6(r); Larix decidua c 10(r); Lophocolea heterophylla 3(+); Oxalis acetosella 5(+); Oxyrrhynchium hians 5(+); Padus serotina b/c 10(+/+), 11(+/); Plantago media (FB) 6(+); Poa compressa s.s. (FB) 11(+); Polygala comosa (FB) 2(r); Rhytidiadelphus triquetrus 2(1.2); Rubus grabowskii $3(+), 7(+)$; Salix caprea b/c 2(+/r), 7(+/); Seseli annuum (FB) 6(r); Thalictrum aquilegiifolium 4(r). 
(2001) oraz Brzega i in. (2009), grupę subasocjacji wyraźnie kserotermicznych i jeden tylko podzespół P.a.-Q. brachypodietosum pinnati Wojterska et Wiszniewska 1996 ex Brzeg et Kasprowicz 2001. Z gatunków wyróżniających tę subasocjację stałym i często rosnącym obficie składnikiem płatów zespołu jest Brachypodium pinnatum (ryc. 3). Dość powszechnie występują m.in.: Anthericum ramosum, Euphorbia cyparissias i Trifolium alpestre (por. tab. 1, 2 i 3), a z drugiej strony niemal zupełnie brak gatunków wilgociolubnych (np. Selinum carvifolia, ryc. 5), diagnostycznych dla grupy podzespołów wilgotnych z Molinia caerulea (por. Brzeg, Kasprowicz 2001; Ratyńska i in. 2010). W ramach podzespołu wyodrębniono dwa warianty: z Pleurozium schreberi i z Asarum europaeum.

Wariant z Pleurozium (tab. 1) wyróżnia lokalnie dziewięć gatunków, w tym siedem reprezentujących klasę Vaccinio-Piceetea. Występowanie płatów tego wariantu jest związane z podłożami mniej lub bardziej kwaśnymi (lub wtórnie zakwaszonymi). Na badanym terenie płaty takie są znacznie rzadziej spotykane. W obrębie omawianego wariantu wyróżniono dwie lokalne postacie. Postać „sosnowa”, udokumentowana jedynie między Pradłami a Białą Błotną (zdj. 1-8), odznacza się dominacją w drzewostanie nasadzonej sosny (ryc. 3) i niemal zupełnym brakiem dębów w najwyższym piętrze, udziałem Populus tremula i gatunków porębowych w niższych warstwach, a mniejszą rolą niektórych roślin klasy Querco-Fagetea. Jednak tylko tam występuje Potentilla albasztandarowy gatunek charakterystyczny zespołu. Postać „dębowa” (zdj. 9-12), spotykana między Kusiętami a Srockiem w paśmie góry Psi Nos, różni się od poprzedniej nie tylko składem drzewostanu, ale też nieco mniejszym udziałem acydofilnych mchów wyróżniających wariant, za to większą rolą m.in. leszczyny i innych gatunków klasy Querco-Fagetea (ryc. 6). Reprezentuje ona, jak się wydaje, znacząco mniej zniekształconą postać podzespołu, a zarazem stanowi ogniwo pośrednie do nieobecnego zupełnie na terenie badań wariantu typowego (por. Brzeg, Kasprowicz 2001).

Fitocenozy wariantu z Asarum (tab. 2), oprócz braku wielu roślin acydofilnych, odznaczają się grupowym udziałem roślin związanych z siedliskami żyznymi, głównie charakterystycznych dla rzędu Fagetalia sylvaticae (por. też tab. 3). Do najważniejszych z nich należą: Aegopodium podagraria, Asarum europaeum, Campanula trachelium, Galeobdolon luteum, Lathyrus vernus i Lilium martagon, diagnostyczne dla takiego wariantu generalnie w całym zasięgu zespołu (Brzeg i in. 2009), a lokalnie też Mercurialis perennis (ryc. 5). W obrębie wariantu na terenie badań wyróżniono dwa podwarianty: nieco bardziej termofilny z Melampyrum nemorosum (zdj. 1-14) oraz typowy (zdj. 15-23).

Udokumentowane na obszarze badań fitocenozy Potentillo albae-Quercetum pod względem geograficznym zdają się reprezentować odmianę małopolską (lub szerzej ujmowaną mazowiecko-małopolską, por. Matuszkiewicz J. M., Kozłowska 1991; Matuszkiewicz J. M. 2005; Wojterska i in. 2007; Brzeg i in. 2009; 


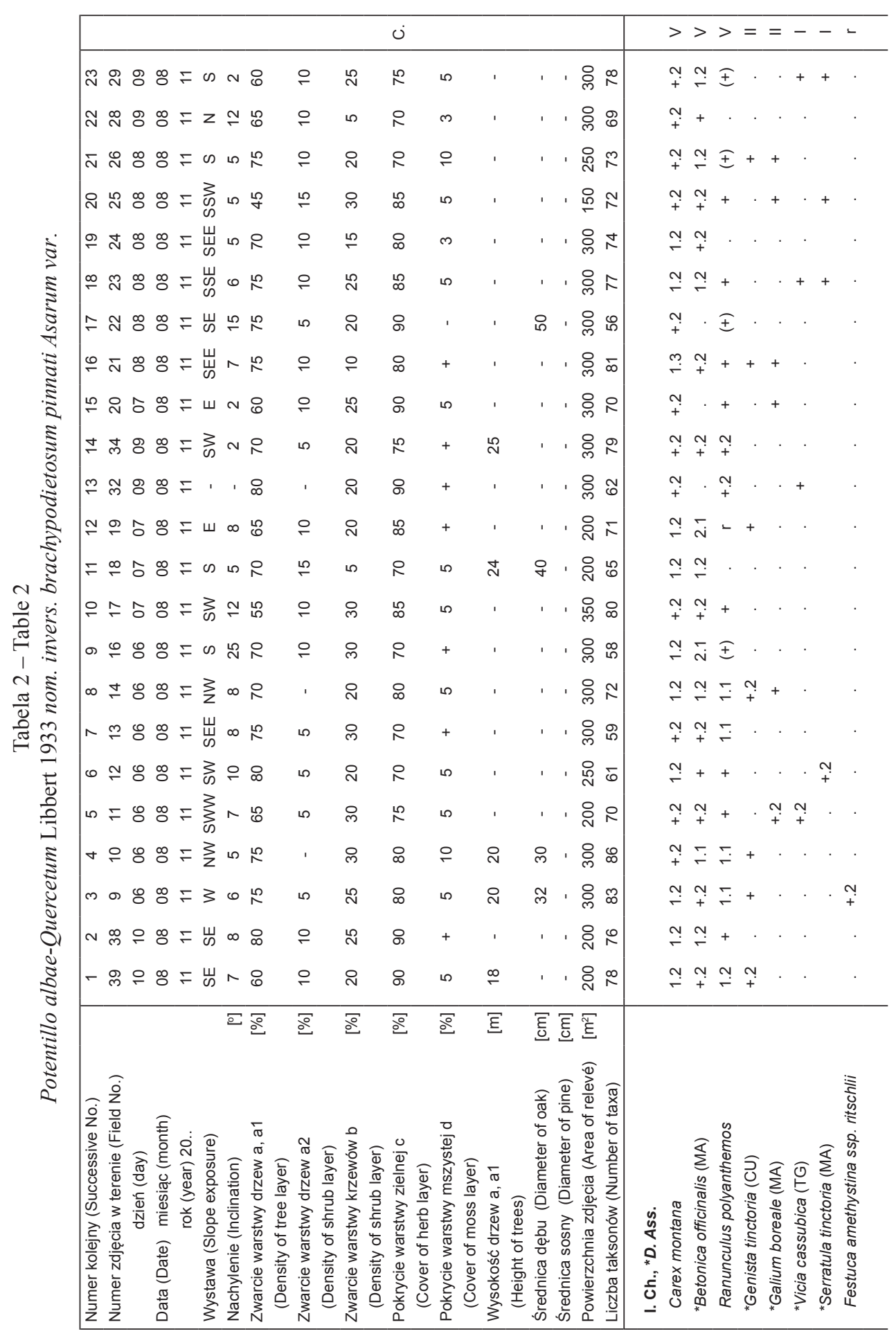




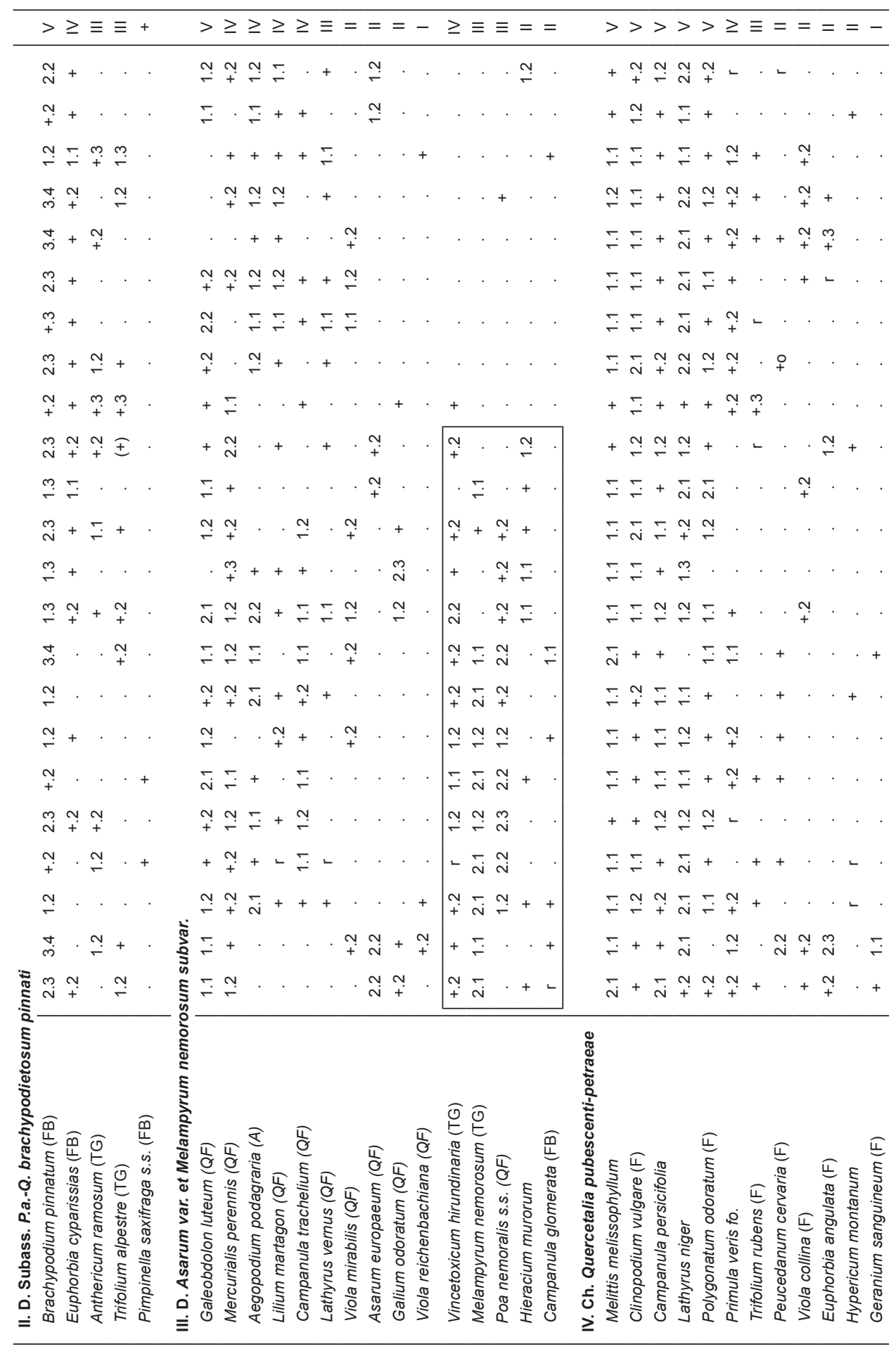




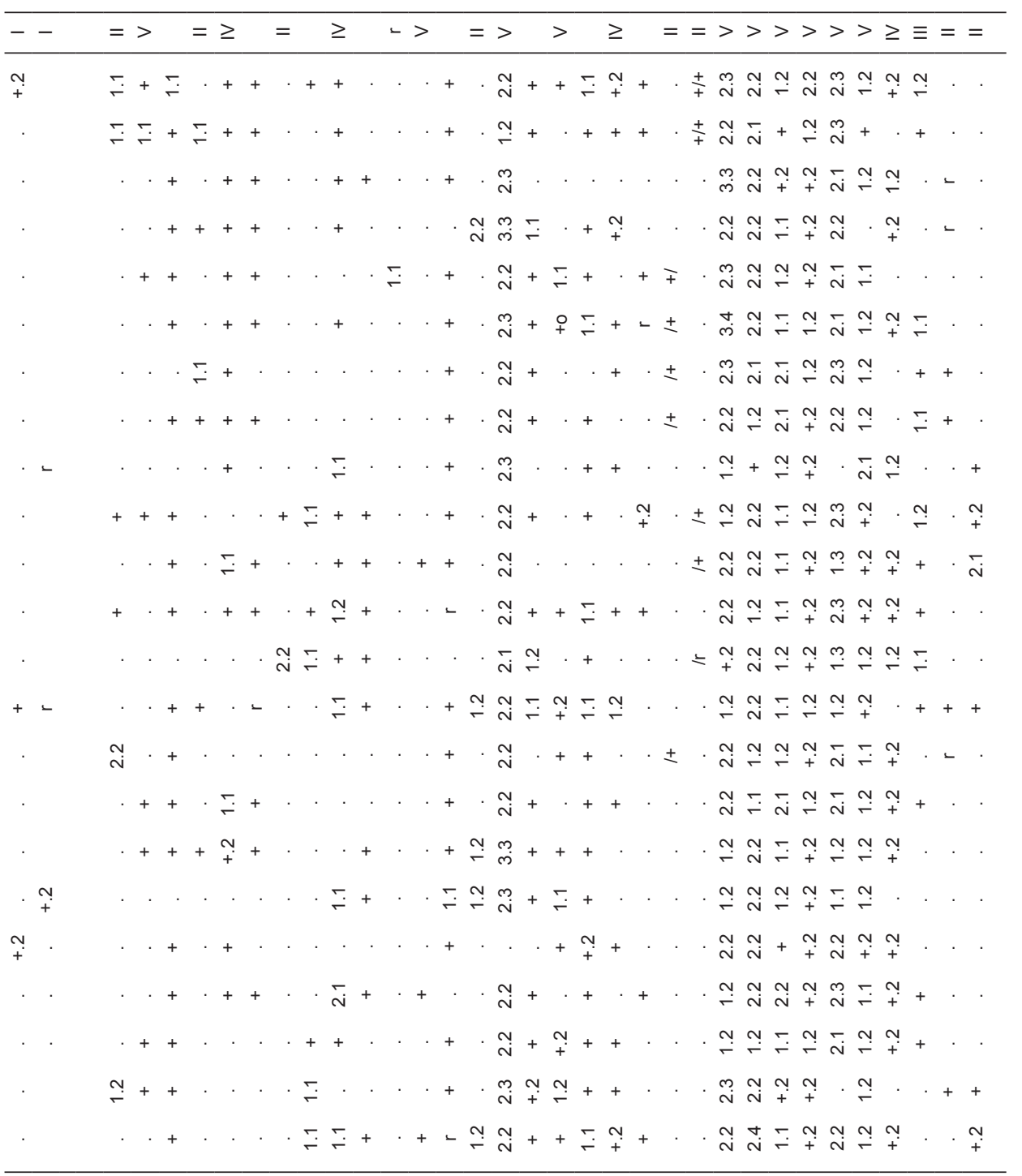

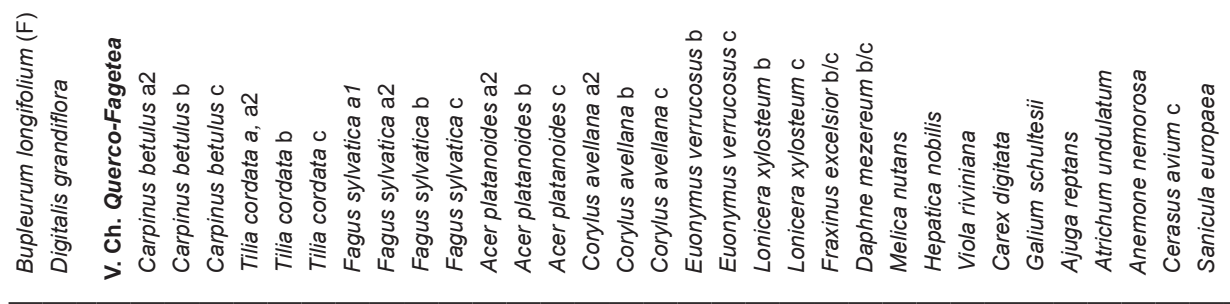




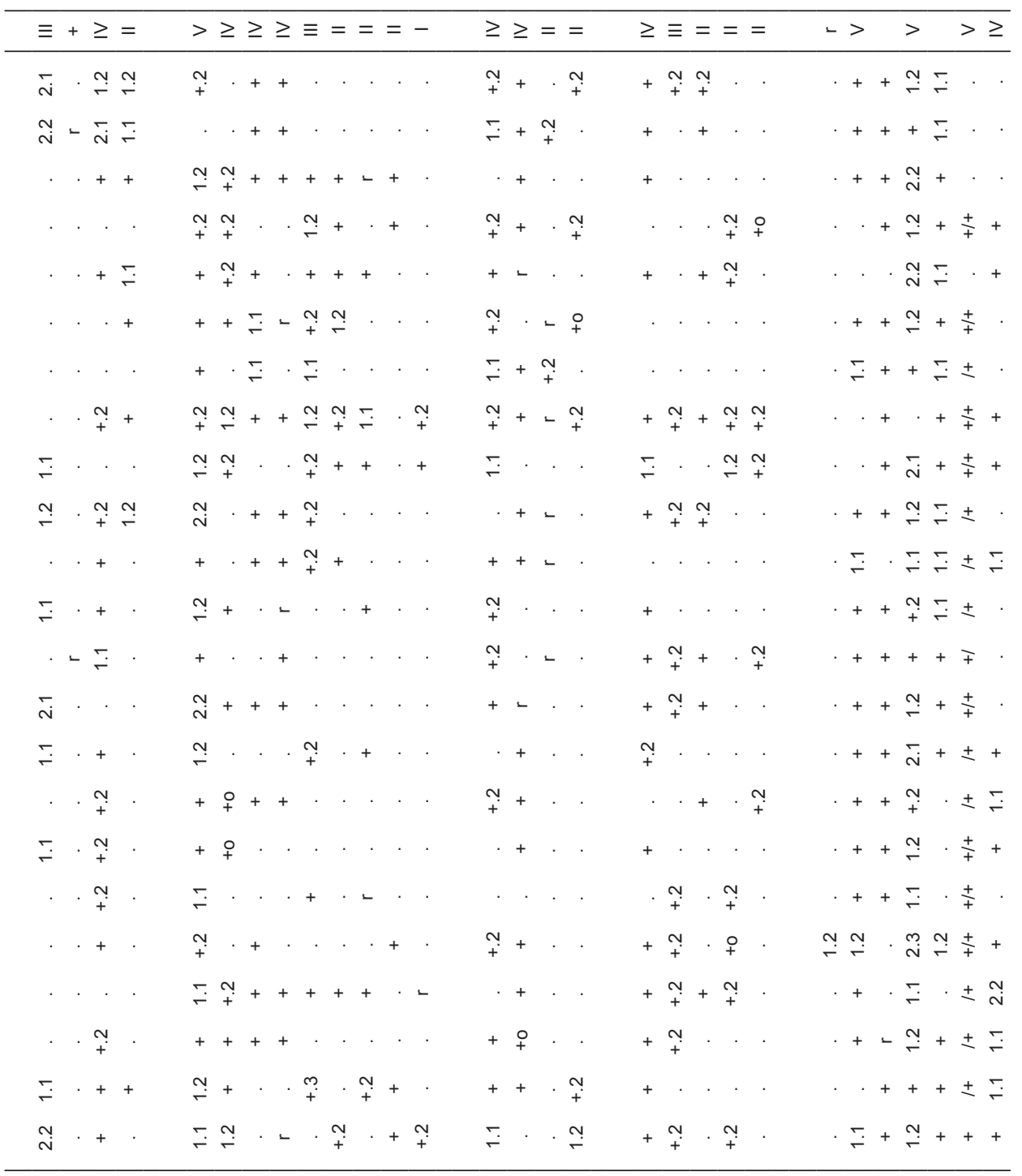

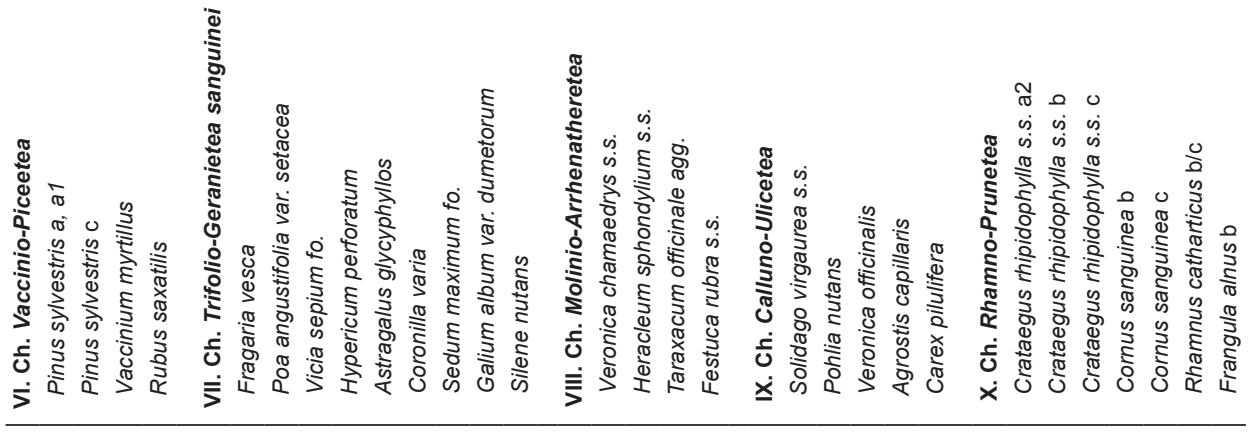




\begin{tabular}{|c|c|c|c|c|c|c|c|c|c|c|c|c|c|c|c|c|c|c|c|c|}
\hline 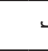 & $-\geq \geq$ & & $\equiv$ & & & $=$ & $>$ & $>$ & $>$ & $\equiv$ & & $\geq=$ & + & + & & - & & -- & - & $->=>>>>$ \\
\hline . & \pm & & \pm & & & + & $\bar{m}$ & $\bar{i}$ & 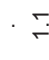 & & & & & • & & & & $\cdot$ & & $\cdot+\stackrel{+}{+} \cdot \check{i} \underset{+}{\stackrel{N}{+}}$ \\
\hline+ & & + & & & & + & $\stackrel{+}{\stackrel{+}{*}}$ & & 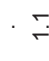 & & & \pm & & . & . & & & $=$ & & 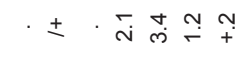 \\
\hline+ & $=+$ & + + & & $\stackrel{t}{+}$ & · & . & $\stackrel{+}{+}$ & 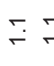 & 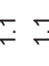 & $\because$ & & \pm & & . & \pm & & & & & $=\bar{i} \stackrel{m}{i} \cdot \stackrel{N}{+}$ \\
\hline+ & $=$ & + & & & & & $\stackrel{m}{m}$ & ++ & +5 & & & $\stackrel{+}{+}$ & & . & 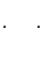 & + & 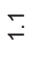 & $\mp$ & & 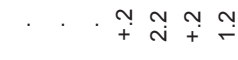 \\
\hline+ & 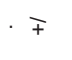 & & \pm & & & ++ & $\stackrel{+}{+}$ & $\check{7}$ & 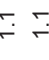 & & & \pm & & & $=\frac{+}{+}$ & & & $\cdot+$ & & 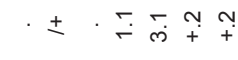 \\
\hline$\cdot+$ & $+\mp$ & + & $\stackrel{+}{+}$ & & - & - & $\stackrel{+}{+}$ & $\stackrel{N}{N}$ & & $\bar{i}$ & & \pm+ & & . & .. & + & + & & $\mp$ & 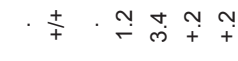 \\
\hline & . . & + & $=$ & \pm & + & $\cdot+$ & $\stackrel{+}{+}$ & $\cdot$ & $\cdot+$ & & & \pm & . & & $\cdot \pm$ & 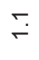 & . & . & & 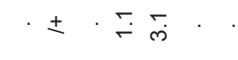 \\
\hline+ & . . & + & \pm & & . & . & $\stackrel{+}{+}$ & $\bar{i}+$ & +5 & & + & $=$ & . & & $= \pm$ & & . & : & 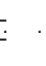 & $\cdot \pm \cdot \bar{i} \underset{+}{+} \stackrel{\sim}{+} \cdot$ \\
\hline+ & . . & 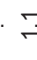 & & & + & + & $\stackrel{m}{m}$ & $\cdot$ & & 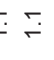 & & \pm & . & . & & $\bar{i}$ & & 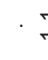 & 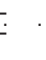 & 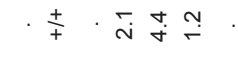 \\
\hline+ & $\cdot \stackrel{\llcorner}{+}$ & + & . & \pm & + & + & $\stackrel{+}{+}$ & ++ & +5 & & & & & & . . & · & & $\mp$ & & $\cdot \stackrel{+}{+} \cdot \stackrel{\sim}{\sim} \underset{m}{\infty} \stackrel{\sim}{+} \underset{+}{\stackrel{N}{+}}$ \\
\hline+ & $\cdot \pm$ & & \pm & & + & $\stackrel{+}{+}$ & $\forall$ & $\cdot$ & $\cdot \bar{N}$ & & . & & & . & . . & . & $\cdot$ & . & & 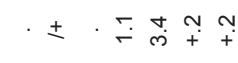 \\
\hline- & $=$ & + & \pm & & + & + & $\stackrel{+}{+}$ & $\bar{i}$ & & 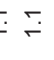 & & \pm 7 & & . & .. & . & 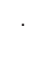 & $\cdot$ & & 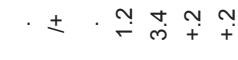 \\
\hline . & . & + & $=$ & & + & + & & $\bar{i}+$ & $+\check{5}$ & $\dot{F}$ & & \pm & & $\cdot$ & $\cdot \frac{+}{+}$ & & 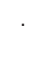 & $\cdot 7$ & $=$ & $\cdot \pm \cdot \overline{\text { N }} \underset{\dot{m}}{\stackrel{N}{\longrightarrow} \underset{+}{+}}$ \\
\hline . & . & & $=$ & \pm & + & + & & $\bar{i}$ & & + & & \pm 7 & & . & . & & . & . & & 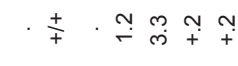 \\
\hline+ & . . & & $=$ & & . & . & $\stackrel{+}{+}$ & . & & $\bar{j} \check{F}$ & & $\stackrel{+}{+}$ & & $\cdot$ & . . & · & . & . & · & 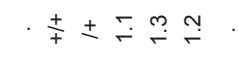 \\
\hline+ & $\cdot \stackrel{+}{+}$ & 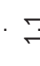 & & & . & . & $\stackrel{\leftrightarrow}{+}$ & $\cdot+$ & $+F$ & $=$ & & & & . & . . & . & . & & . & 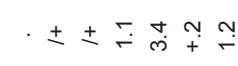 \\
\hline . & $\cdot \stackrel{+}{+}$ & 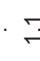 & 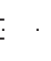 & . & & & $\stackrel{\leftrightarrow}{+}$ & ++ & $+F$ & & & & & . & & & & & . & 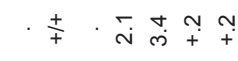 \\
\hline+ &.$\mp$ & & $=$ & . & & $\cdot+$ & $\stackrel{+}{\stackrel{4}{4}}$ & $\cdot 7$ & $\check{\sim}$ & $\overline{\mathrm{N}} \check{\zeta}$ & & & & . & $=$ & & & & . & 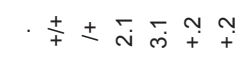 \\
\hline+ & $\cdot \pm$ & & & $\stackrel{t}{+}$ & . & . & $\stackrel{+}{\leftrightarrow}$ & $\stackrel{\sim}{\sim} \underset{7}{7}$ & $\stackrel{+}{\sim}$ & + & & $\stackrel{+}{+}$ & & . & . . & . & . & & & 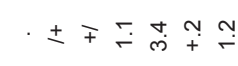 \\
\hline & $\cdot \pm$ & $\tau$ & & & . & . & $\stackrel{\leftrightarrow}{+}$ & $\cdot+$ & ++ & $+\stackrel{5}{-}$ & & \pm 7 & & & . $\mp$ & & . & . & & $\cdot \pm \underset{+}{+} \overline{\mathrm{N}} \underset{+}{\forall} \underset{+}{\stackrel{N}{+}}$ \\
\hline+ & $\mp$ & 7 & & & $\cdot$ & . & $\stackrel{+}{+}$ & $\check{r}$ & & $\therefore$ & & \pm 7 & & & $=$ & & . & . & & 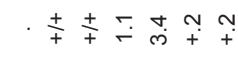 \\
\hline+ & $\cdot \pm+$ & + & & & & . & $\stackrel{+}{+}$ & 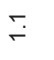 & $\cdot$ & & & \pm & . & . & . & & & . & & . $\pm \cdot \bar{i} \stackrel{m}{+} \underset{+}{+}$ \\
\hline & $\cdot \cdot+$ & + & & \pm & & . & $\stackrel{\leftrightarrow}{\oplus}$ & $\check{r}+$ & $+\bar{i}$ & & & & & & & & & & & $+ \pm \mp \overline{\mathrm{N}} \cdot \underset{+}{\stackrel{N}{+}}$ \\
\hline
\end{tabular}

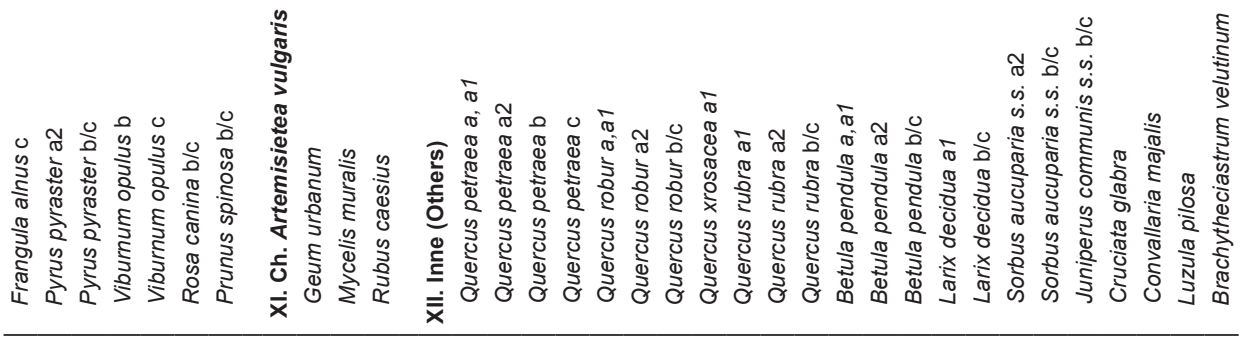




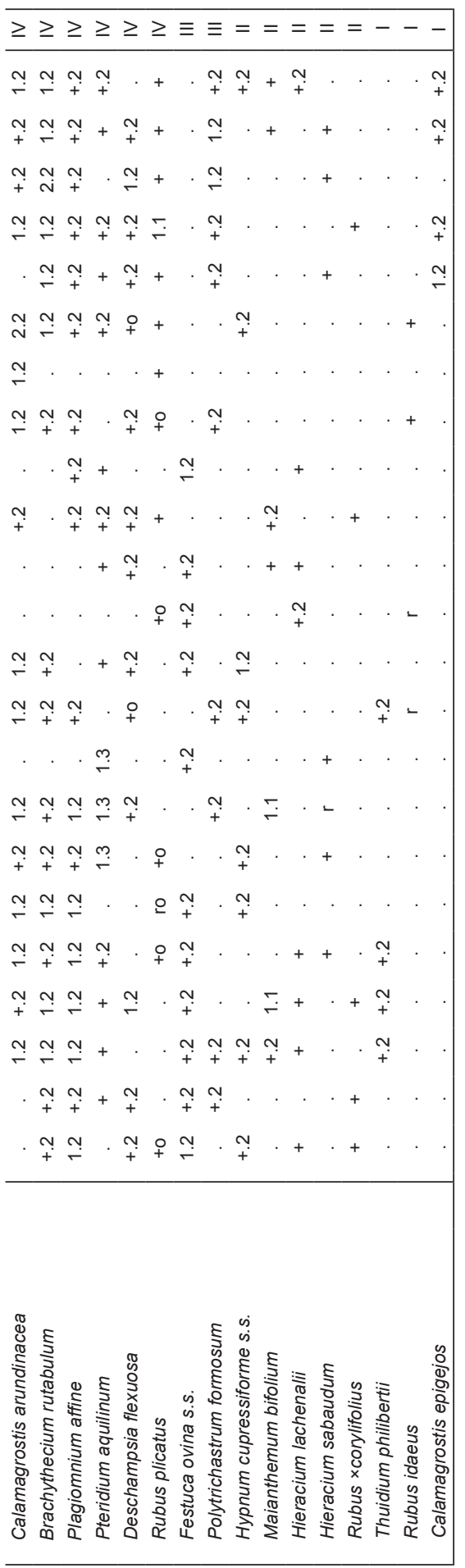

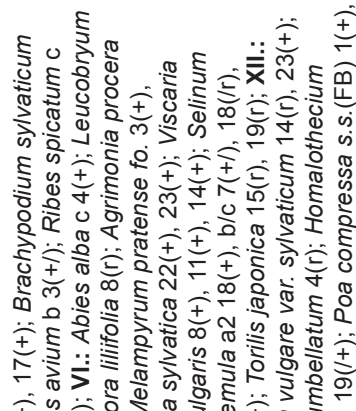

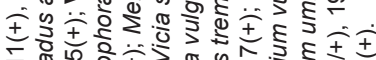

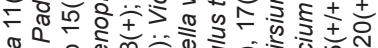

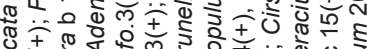

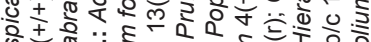

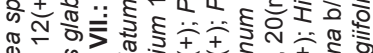

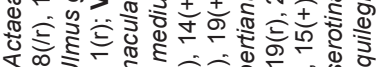

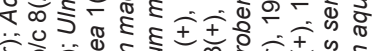

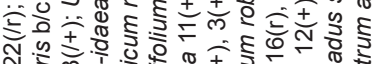

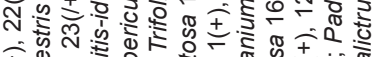

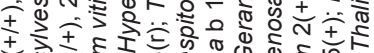

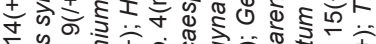

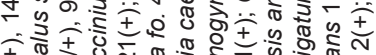

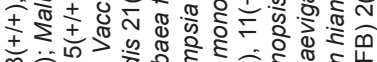
क人⿻上丨

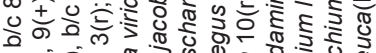

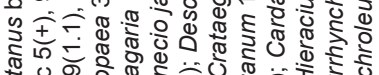
कृ

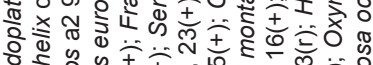
วิ के की क人

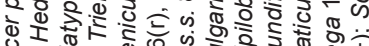

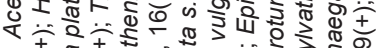

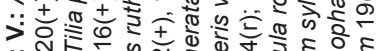

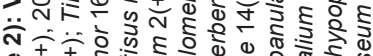

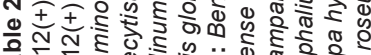

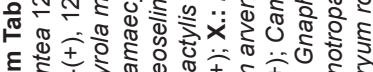

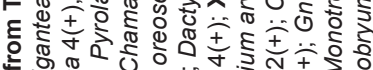

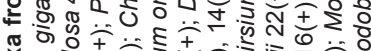
要 㻤

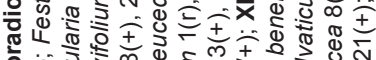

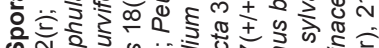

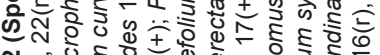

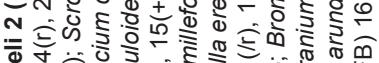

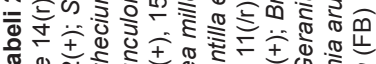

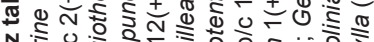
N

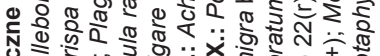

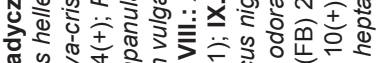

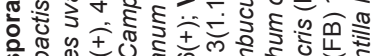

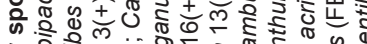

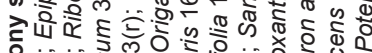

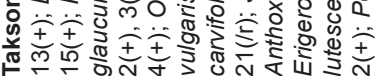


Ratyńska i in. 2010). Przemawia za tym obecność m.in.: Bupleurum longifolium, Chamaecytisus ruthenicus, Cruciata glabra, Euphorbia angulata, Galium schultesii, Melittis melissophyllum i Viola collina.

\section{Znaczenie zespołu dla ochrony różnorodności biologicznej regionu}

Ciepłolubna dąbrowa typu Potentillo albae-Quercetum zajmuje ważne miejsce w programie Natura 2000. Jak wspominano, stanowi siedlisko priorytetowe - 91I0, które jest przedmiotem zainteresowania Wspólnoty (Rozporządzenie Ministra... 2013; Obwieszczenie Ministra... 2014). Ma więc istotne znaczenie dla ochrony różnorodności biologicznej także na badanym obszarze Wyżyny Krakowsko-Częstochowskiej zarówno w odniesieniu do świata roślin, jak i zwierząt. W obrębie Ostoi Olsztyńsko-Mirowskiej wiele gatunków ma tam dziś jedyne ostoje $\mathrm{w}$ obrębie formacji leśnej $\mathrm{z}$ udziałem badanych fitocenoz. W licznych jaskiniach przebywa stale bądź okresowo kilka gatunków nietoperzy: podkowiec mały Rhinolophus hipposideros, nocek duży Myotis myotis, nocek orzęsiony M. emarginatus, nocek Bechsteina M. bechsteinii i mopek zachodni Barbastella barbastellus, które wymagają ochrony w formie wyznaczenia obszaru Natura 2000 (Czechowski i in. bez daty; Obwieszczenie Ministra... 2014). Podobny status wśród roślin naczyniowych ma dzwonecznik wonny Adenophora liliifolia (ryc. 7), stwierdzony zaledwie w czterech kwadratach o boku $2 \mathrm{~km}$ na 430 podstawowych pól badawczych całej wyżyny (Urbisz 2004).

O niezwykle ważnej roli badanego zespołu świetlistej dąbrowy Potentillo albae-Quercetum w zachowaniu cennych elementów flory świadczą też liczby gatunków unikatowych (tab. 3): prawnie chronionych (17), umieszczonych na polskiej czerwonej liście roślin naczyniowych (6), w różnym stopniu zagrożonych w województwie śląskim (67) bądź uznanych za bardzo rzadkie i rzadkie na Wyżynie Krakowsko-Częstochowskiej (29). Cztery gatunki spośród 250 taksonów zestawionych w tabelach 1 i 2 podlegają aktualnie ochronie ścisłej. Dotyczy to wyłącznie roślin naczyniowych, tj.: Adenophora liliifolia, Bupleurum longifolium, Festuca amethystina i Lilium martagon. $\mathrm{Z}$ wyjątkiem lilii złotogłów trzy pozostałe mają tylko pojedyncze, rozproszone stanowiska, ograniczone do kilku zaledwie kęp bądź skupisk i są spotykane wyłącznie na obszarze Ostoi Olsztyńsko-Mirowskiej. Pięć innych gatunków roślin kwiatowych: Daphne mezereum, Digitalis grandiflora, Epipactis helleborine, Melittis melissophyllum oraz Pyrola minor są objęte ochroną częściową, podobnie jak osiem gatunków mchów właściwych: Calliergonella cuspidata, Eurhynchium angustirete, Leucobryum glaucum, Pleurozium schreberi, Pseudoscleropodium purum, Rhytidiadelphus squarrosus, Rh. triquetrus i Thuidium philibertii (Rozporządzenie Ministra... 2014). 


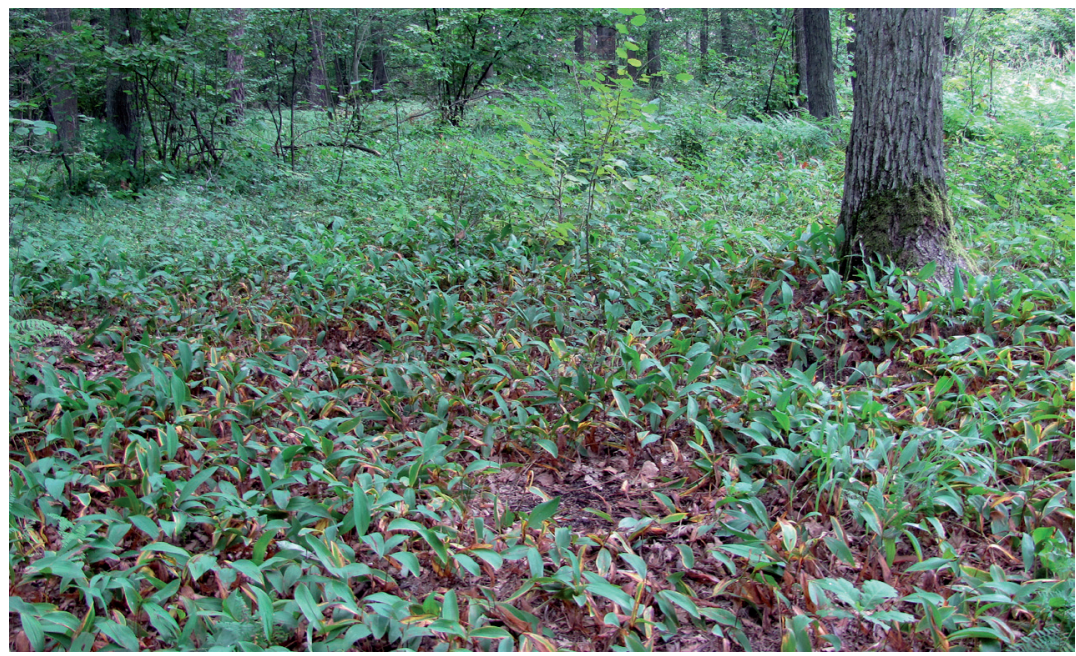

Ryc. 6. Płat Potentillo albae-Quercetum brachypodietosum pinnati w wariancie z Pleurozium, z naturalnym drzewostanem dębowym i bogatym runem z dominacją Convallaria majalis oraz udziałem m.in. Pteridium aquilinum i Vicia cassubica na górze Psi Nos koło Kusiąt. Fot. S. Wika, 9.08.2011 r.

Fig. 6. A patch of the Potentillo albae-Quercetum brachypodietosum pinnati Pleurozium var. with natural oak stand and floristically rich herb layer, dominated by Convallaria majalis with a share of Pteridium aquilinum and Vicia cassubica on Psi Nos hill near Kusięta. Phot. S. Wika, 9.08.2011

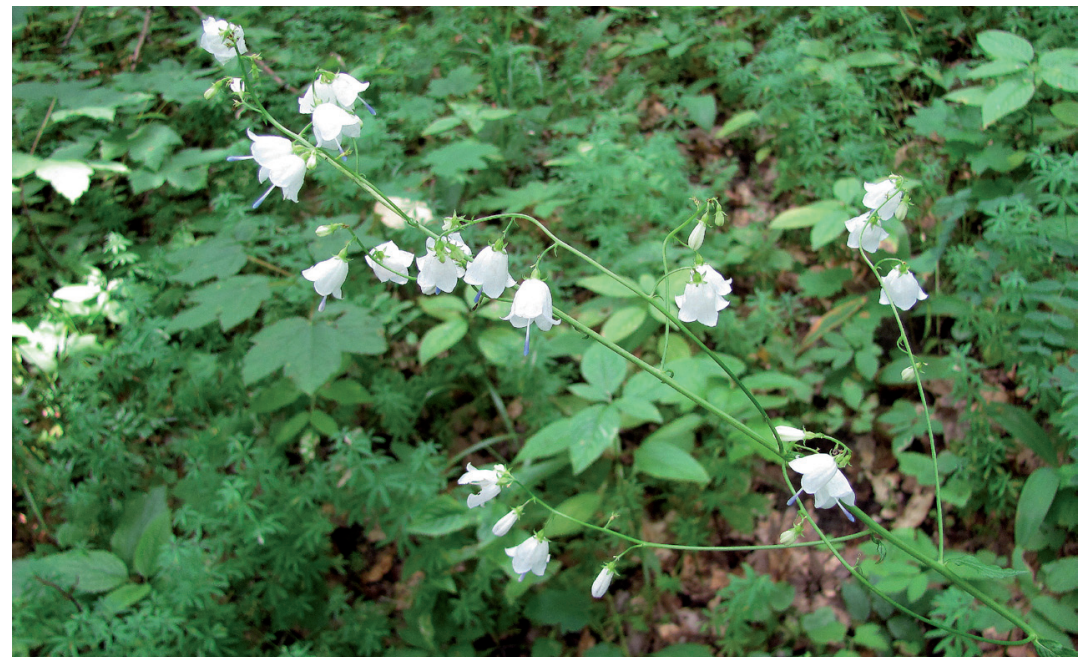

Ryc. 7. Okaz Adenophora liliifolia w płacie Potentillo albae-Quercetum na górze Liboradz koło Srocka. Fot. S. Wika, 6.08.2011 r.

Fig. 7. A speciment of very rare Natura 2000 species Adenophora liliifolia in a patch of Potentillo albae-Quercetum on Liboradz hill near Srocko. Phot. S. Wika, 6.08.2011 
Tabela 3 - Table 3

Ważne cechy charakterystyczne zespołu Potentillo albae-Quercetum w środkowej części

Wyżyny Krakowsko-Częstochowskiej

Important features of the Potentillo albae-Quercetum in the central part of the

Kraków-Częstochowa Upland

\begin{tabular}{|c|c|c|c|}
\hline Podzespół (Subassociation) & \multicolumn{3}{|c|}{ P.a.-Q. brachypodietosum pinnati } \\
\hline Wariant z (Variant) & Pleurozium & Asarum & Ogółem (Total) \\
\hline Liczba zdjęć (Number of relevés) & 12 & 23 & 35 \\
\hline \multicolumn{4}{|l|}{ Ch., ${ }^{*}$ D. Ass. } \\
\hline Ranunculus polyanthemos & $V^{r-1}$ & $V^{r-1}$ & V \\
\hline Carex montana & $\mathrm{IV}^{+-2}$ & $\mathrm{~V}^{+-1}$ & V \\
\hline${ }^{*}$ Betonica officinalis & $\mathrm{II}^{+}$ & $\mathrm{V}^{+-2}$ & IV \\
\hline${ }^{*}$ Galium boreale & $\mathrm{IV}^{+}$ & $\mathrm{II}^{+}$ & III \\
\hline Potentilla alba & $\mathrm{IV}^{+-2}$ & . & II \\
\hline${ }^{*}$ Genista tinctoria & $\mathrm{II}^{+}$ & $\mathrm{II}^{+}$ & II \\
\hline *Vicia cassubica & $\| I^{1-2}$ & $\mathrm{I}^{+}$ & 1 \\
\hline *Serratula tinctoria & . & $\mathrm{I}^{+}$ & I \\
\hline Festuca amethystina ssp. ritschlii & . & $r$ & $r$ \\
\hline \multicolumn{4}{|l|}{ D. Subass. } \\
\hline Brachypodium pinnatum & $\mathrm{V}^{+-5}$ & $\mathrm{~V}^{+-3}$ & V \\
\hline Euphorbia cyparissias & $\mathrm{III}^{r-+}$ & $\mathrm{IV}^{+-1}$ & IV \\
\hline Trifolium alpestre & $\mathrm{III}^{+}$ & $\mathrm{III}^{+-1}$ & III \\
\hline Anthericum ramosum & $\mathrm{II}^{+-2}$ & $\mathrm{III}^{+-1}$ & II \\
\hline Pimpinella saxifraga s.s. & $\mathrm{III}^{\mathrm{r}-+}$ & + & II \\
\hline \multicolumn{4}{|l|}{ D. var. } \\
\hline Pleurozium schreberi & $\mathrm{V}^{+-2}$ & . & II \\
\hline Vaccinium vitis-idaea & $\mathrm{IV}^{r-1}$ & $r$ & II \\
\hline Potentilla erecta & $\mathrm{IV}^{+}$ & $\mathrm{I}^{+}$ & II \\
\hline Melampyrum pratense fo. & $\mathrm{III}^{\mathrm{r}-2}$ & . & 1 \\
\hline Pseudoscleropodium purum & $\mathrm{III}^{+}$ & . & 1 \\
\hline Sciuro-hypnum oedipodium & $\mathrm{III}^{+-2}$ & . & 1 \\
\hline Danthonia decumbens & $\mathrm{II}^{+}$ & . & 1 \\
\hline Trientalis europaea & $\mathrm{II}^{+}$ & $r$ & 1 \\
\hline Orthilia secunda & $\mathrm{II}^{\mathrm{r-+}}$ & . & + \\
\hline Galeobdolon luteum & . & $\mathrm{V}^{+-2}$ & III \\
\hline Mercurialis perennis & $\mathrm{II}^{+}$ & $\mathrm{IV}^{+-2}$ & III \\
\hline Aegopodium podagraria & . & $\mathrm{IV}^{+-2}$ & III \\
\hline Lilium martagon & . & $\mathrm{IV}^{\mathrm{r}-1}$ & III \\
\hline Campanula trachelium & $\mathrm{I}^{r-+}$ & $\mathrm{IV}^{+-1}$ & III \\
\hline Melampyrum nemorosum & + & $\mathrm{III}^{+-2}$ & II \\
\hline Lathyrus vernus & . & $\mathrm{III}^{\mathrm{r}-1}$ & II \\
\hline Viola mirabilis & . & $\mathrm{II}^{+-1}$ & II \\
\hline Asarum europaeum & . & $\mathrm{II}^{+-2}$ & 1 \\
\hline Galium odoratum & + & $\mathrm{II}^{+}$ & 1 \\
\hline Viola reichenbachiana & . & $\mathrm{I}^{+}$ & + \\
\hline $\begin{array}{l}\text { Liczba taksonów roślin naczyniowych } \\
\text { (Number of vascular plant taxa) }\end{array}$ & 159 & 174 & 226 \\
\hline $\begin{array}{l}\text { Liczba taksonów mszaków } \\
\text { (Number of bryophyte taxa) }\end{array}$ & 22 & 13 & 24 \\
\hline
\end{tabular}




\begin{tabular}{|c|c|c|c|}
\hline \multicolumn{4}{|l|}{$\begin{array}{l}\text { Klasy roślinności z największą liczbą taksonów } \\
\text { (Phytosociological classes with the highest } \\
\text { number of taxa) }\end{array}$} \\
\hline Querco-Fagetea & 39 & 53 & 55 \\
\hline Trifolio-Geranietea sanguinei & 26 & 34 & 36 \\
\hline Molinio-Arrhenatheretea & 16 & 12 & 18 \\
\hline Rhamno-Prunetea & 13 & 12 & 14 \\
\hline Calluno-Ulicetea & 12 & 7 & 12 \\
\hline Festuco-Brometea & 12 & 9 & 14 \\
\hline Vaccinio-Piceetea & 10 & 9 & 12 \\
\hline \multicolumn{4}{|c|}{ Rodzaje najbogatsze w taksony (Genera with the highest number of taxa) } \\
\hline Rubus & 8 & 5 & 8 \\
\hline Hieracium & 4 & 5 & 6 \\
\hline Campanula & 4 & 5 & 5 \\
\hline Galium & 5 & 4 & 5 \\
\hline Quercus & 3 & 4 & 4 \\
\hline Carex & 4 & 3 & 4 \\
\hline Festuca & 3 & 4 & 4 \\
\hline Vicia & 3 & 3 & 4 \\
\hline Viola & 2 & 4 & 4 \\
\hline \multicolumn{4}{|c|}{$\begin{array}{l}\text { Liczba gatunków prawnie chronionych - w nawiasie ochrona częściowa (Number of species protected by law - } \\
\text { partially protected in brackets) }\end{array}$} \\
\hline Rośliny naczyniowe (vascular plants) & $4(4)$ & $9(5)$ & $9(5)$ \\
\hline Mszaki (bryophytes) & $8(8)$ & 2(2) & $8(8)$ \\
\hline $\begin{array}{l}\text { Liczba gatunków z polskiej czerwonej listy roślin } \\
\text { naczyniowych (Number of vascular plant species } \\
\text { from the red list of Poland) }\end{array}$ & - & 6 & 6 \\
\hline \multicolumn{4}{|c|}{ Liczba gatunków zagrożonych w województwie śląskim (Number of threatened species in Silesian voivodship) } \\
\hline Rośliny naczyniowe (vascular plants) & 28 & 35 & 44 \\
\hline Mszaki (bryophytes) & 21 & 13 & 23 \\
\hline $\begin{array}{l}\text { Liczba gatunków roślin naczyniowych bardzo } \\
\text { rzadkich i rzadkich na Wyżyny Krakowsko- } \\
\text {-Częstochowskiej (Number of very rare and } \\
\text { rare species of vascular plants in the Kraków- } \\
\text { częstchowa Upland) }\end{array}$ & 18 & 24 & 29 \\
\hline
\end{tabular}

Blisko 27\% taksonów w płatach tej asocjacji należy w województwie śląskim do zagrożonych (o różnym statusie zagrożenia, por. Fojcik 2011; Parusel, Urbisz 2012; Stebel i in. 2012). Spośród tej grupy zagrożenie w skali całego kraju wykazuje sześć z nich, co stanowi ponad $2 \%$ stwierdzonej flory (por. Kaźmierczakowa $i$ in. 2016). W zamieszczonym niżej wykazie te ostatnie opatrzono gwiazdką (*): CR - Adenophora liliifolia*; EN - Bupleurum longifolium*, Chamaecytisus ruthenicus, Festuca amethystina*, Potentilla alba; VU - Alchemilla glaucescens, Bromus benekenii, Carex montana, Euphorbia angulata, Hypericum montanum, Melittis melissophyllum, Rubus grabowskii, R. gracilis, R. pedemontanus, $R$. saxatilis, Trifolium rubens*, Vicia cassubica, V. sylvatica, Viola mirabilis; NT - Anthericum ramosum, Geranium sanguineum, G. sylvaticum*, Hepatica nobilis, Leucobryum glaucum, Lilium martagon, Peucedanum cervaria, Rhytidiadelphus triquetrus, Rosa dumalis, Serratula tinctoria, Seseli 
annuum, Trifolium alpestre, Vincetoxicum hirundinaria, Viola collina; $\mathbf{L C}-A c$ taea spicata, Agrimonia procera, Atrichum undulatum, Brachytheciastrum velutinum, Brachythecium rutabulum, Calliergonella cuspidata, Carex pilulifera, Daphne mezereum, Dicranella heteromalla, Digitalis grandiflora, Euonymus verrucosus, Genista germanica, Homalothecium lutescens, Eurhynchium angustirete, Hypnum cupressiforme s.s., Lathyrus niger, Lophocolea heterophylla, Orthilia secunda, Oxyrrhynchium hians, Plagiomnium affine, Plagiothecium curvifolium, Pleurozim schreberi, Pohlia nutans, Polytrichastrum formosum, Polytrichum juniperinum, Potentilla heptaphylla, Primula veris, Pseudoscleropodium purum, Rhodobryum roseum, Rhytidiadelphus squarrosus, Sciurohypnum oedipodium, Thalictrum aquilegiifolium, Thuidium philibertii, Viscaria vulgaris; DD - Monotropa hypophaega*.

Warto także przedstawić, za Urbiszem (2004, 2008), wszystkie taksony uznane przez autora za bardzo rzadkie (!) i rzadkie na obszarze Wyżyny Krakowsko-Częstochowskiej, a które podczas naszych badań zostały stwierdzone w fitocenozach świetlistej dąbrowy. Są nimi: Adenophora liliifolia (!), Agrimonia procera, Alchemilla glaucescens, Bromus benekenii, Buplerum longifolium, Carex montana, C. pilulifera, Chamaecytisus ruthenicus, Crataegus rhipidophylla s.s., Euphorbia angulata, Geranium sylvaticum (!), Hieracium laevigatum, Hypericum montanum, Molinia arundinacea, Monotropa hypophaega (!), Poa angustifolia, Potentilla alba (!), Ranunculus polyanthemos, Rosa dumalis, Rubus $\times$ corylifolius (!), R. grabowskii (!), Rubus gracilis (!), R. saxatilis, Serratula tinctoria, Thalictrum aquilegiifolium, Trifolium rubens oraz Vicia cassubica (!). Taksonami nowymi dla interesującego nas obszaru okazały się Festuca amethystina i Quercus × rosacea.

\section{DYSKUSJA}

Zespół Potentillo albae-Quercetum okazał się nowym typem roślinności dla obszaru środkowej części Wyżyny Krakowsko-Częstochowskiej. Z całej Wyżyny Śląsko-Krakowskiej (w szerokim ujęciu) znany był on wcześniej tylko z jej północnej części, tj. z Wyżyny Wieluńskiej (Kurowski 1979; Kurzac 1984, 1986; Hereźniak 1993), gdzie występował głównie w zubożałych postaciach, reprezentując, jak wynika z naszej analizy zaprezentowanego tam materiału, niemal wyłącznie podzespół typowy w wariancie z Pleurozium.

Z obszaru badań, a dokładnie z rezerwatu Zielona Góra i okolic Zrębic, Hereźniak (l.c.) udokumentował obecność innego syntaksonu z rzędu Quercetalia pubescenti-petraeae, mianowicie ciepłolubnych zarośli leszczynowych zbliżonych do Peucedano cervariae-Coryletum Kozłowska 1925 em. Medw.-Kornaś 1952 nom. invers., zespołu podawanego także z położonej dalej na południe Wyżyny Krakowskiej (Medwecka-Kornaś 1952; Medwecka-Kornaś i Kornaś 
1963; Michalik 1980; Bąba 2002 i in.). Z analizy zdjęć fitosocjologicznych Hereźniaka (1993) wynika jednak, że chodziło nie o ten ostatni zespół (brak podstawowych gatunków diagnostycznych, jak Tanacetum corymbosum, niewielka rola leszczyny, stała obecność drzewostanu), a raczej o młodociane, ulokowane przy skrajach kompleksów leśnych, stadia rozwojowe świetlistej dąbrowy, bardzo zbliżone do scharakteryzowanego w niniejszej pracy termofilnego podwariantu z Melampyrum nemorosum w ramach wariantu z Asarum (por. tab. 2). We wcześniejszym opracowaniu roślinności rezerwatu Zielona Góra (Celiński, Wika 1975) takie fitocenozy nie były uwzględnione, a nieco nawiązujące do nich ciepłolubne lasy zostały zaliczone do grądu miodownikowego Tilio-Carpinetum melittetosum, podobnie jak na innych stanowiskach w obrębie badanego terenu. Warto zauważyć, że zespół Potentillo albae-Quercetum nie został wykazany także na mapach potencjalnej roślinności naturalnej interesującego nas obszaru (Wika 1981; Matuszkiewicz W. i in. 1995). Zważywszy, że wcześniejsze badania fitosocjologiczne zbiorowisk leśnych dotyczyły przede wszystkim rezerwatów przyrody i najlepiej zachowanych kompleksów proponowanych do objęcia ochroną, należy założyć, że ukryte wśród zniekształconych lasów gospodarczych fitocenozy Potentillo albae-Quercetum mogły zostać przeoczone.

Zawarte w artykule materiały mogą stanowić przyczynek do podjętej przez J. M. Matuszkiewicza (2005) dyskusji na temat odrębności tzw. wyżynnej postaci świetlistej dąbrowy. Wydaje się, że fitocenozy obecne w środkowej części Wyżyny Krakowsko-Częstochowskiej, dokumentowane ze stanowisk położonych na wysokościach zbliżonych do 300 m n.p.m., nie wykazują żadnych istotnych cech różniących je od analogicznych zbiorowisk niżowych. Dobrze wyrażają natomiast swoisty charakter geograficzny jako reprezentujące szerzej ujętą odmianę mazowiecką-małopolską (por. Matuszkiewicz J. M., Kozłowska 1991; Matuszkiewicz J. M. 2005) albo węziej - małopolską, która od mazowieckiej miałaby się różnić stałą obecnością m.in. Cruciata glabra, a brakiem Koeleria grandis czy Trifolium lupinaster (por. Kurowski 1976; Wojterska i in. 2007; Brzeg i in. 2009). Odnoszenie wyżynnej postaci Potentillo albae-Quercetum do podzespołu P.a.-Q. rosetosum gallicae nie wydaje się uzasadnione, gdyż następuje w tym przypadku mieszanie zmienności piętrowej (wysokościowej) z lokalnosiedliskową. Wspomniany podzespół jest jednym z kilku reprezentujących grupę subasocjacji wilgotnych (Wojterska i in. l.c.; Brzeg i in. l.c.). Znamienne jest to, że na obszarze badań ta ostatnia grupa nie jest reprezentowana, podobnie jak grupa pośrednich podzespołów „typowych”, a realizuje się tam tylko jeden podzespół (P.a.-Q. brachypodietosum pinnati) z grupy subasocjacji wyraźnie kserotermofilnych. Warto też podkreślić, że po raz pierwszy w literaturze wyróżniono syntaksony w randze subwariantów, co zdaje się przeczyć poglądom o niezbyt dużej zmienności lokalnosiedliskowej interesującego nas zespołu (por. Matuszkiewicz J. M. 2005). Kwestia wieloaspektowego zróżnicowania 
świetlistej dąbrowy nie tylko w Polsce, ale w całym jej obszarze zasięgowym nadal wymaga osobnych studiów.

Trudno dociekać, jakie są przyczyny pewnych różnic, widocznych w lokalnej kompozycji florystycznej zespołu odniesionej do tej z innych terenów. Przede wszystkim zauważa się zupełny brak Pulmonaria angustifolia i rzadkość występowania Potentilla alba w grupie gatunków charakterystycznych zespołu, a także silne zubożenie florystyczne w grupach gatunków: użytków zielonych z klasy Molinio-Arrhenatheretea oraz psiar i wrzosowisk z klasy Calluno-Ulicetea (por. m.in. Kaźmierczakowa 1971; Głazek 1973; Krotoska 1991; Jakubowska-Gabara 1993; Wojterska, Wiszniewska 1996). Być może ma to związek z bardzo słabą penetracją i ingerencją człowieka w istniejących fitocenozach świetlistej dąbrowy, a także z zupełnym zarzuceniem choćby epizodycznego wypasu.

Mimo pewnych braków w charakterystycznej kombinacji gatunków Potentillo albae-Quercetum na obszarze środkowej części Wyżyny Krakowsko-Częstochowskiej stan zachowania zespołu na zdecydowanej większości stanowisk należy uznać za zadowalający. W zasadzie jedynym stwierdzonym zagrożeniem istniejących fitocenoz jest powolny proces przenikania do nich z sąsiednich grądów i wkraczania do podszytu oraz w dolne piętro drzewostanów gatunków zacieniających dno lasu (Carpinus betulus, Tilia cordata; por. Kwiatkowska, Wyszomirski 1988; Jakubowska-Gabara 1993), a miejscami też silny rozrost niektórych krzewów, jak Cornus sanguinea czy Corylus avellana. W takich przypadkach w ramach planów ochrony rezerwatów, parków krajobrazowych bądź obszarów Natura 2000 zalecać należy stosowanie metod aktywnej ochrony fitocenoz świetlistej dąbrowy, polegających na redukowaniu udziału tychże gatunków.

\section{PODSUMOWANIE}

Badania fitosocjologiczne, dotyczące zespołu świetlistej dąbrowy Potentillo albae-Quercetum Libbert 1933 nom. invers. na obszarze środkowej części Wyżyny Krakowsko-Czestochowskiej przeprowadzono w pierwszej dekadzie sierpnia 2011 roku. Obecność w większości wielkopowierzchniowych płatów tej asocjacji, będącej priorytetowym siedliskiem przyrodniczym w programie Natura 2000 o kodzie 91I0, stwierdzono na siedmiu stanowiskach (ryc. 1). W płatach tych wykonano 35 zdjęć fitosocjologicznych, które po analizie zestawiono w tabelach analitycznych 1 i 2.

Stwierdzono, że wszystkie zbadane fitocenozy reprezentują tylko jeden podzespół P.a.-Q. brachypodietosum pinnati, zróżnicowany na dwa warianty: z Pleurozium schreberi (na siedliskach kwaśnych i uboższych) oraz z Asarum europaeum (na siedliskach obojętnych lub zasadowych, ogólnie żyźniejszych), 
ten ostatni zróżnicowany dalej na dwa podwarianty. Zauważono, że charakterystyczna kombinacja zespołu realizuje się zarówno w lasach zbliżonych do naturalnych, z wielopokoleniowymi drzewostanami dębowymi z przewagą Quercus petraea, jak i w zmienionych lasach gospodarczych ze sztucznymi drzewostanami sosnowymi, gdzie zaznaczają się jednak wyraźniejsze procesy degeneracyjne. Podobnie jak na innych obszarach, na terenie badań zespół należy do najbogatszych pod względem florystycznym ekosystemów leśnych (notowano średnio 71 taksonów roślin w zdjęciu, łącznie w całym materiale 250 taksonów roślin naczyniowych i mszaków).

Obecność płatów Potentillo albae-Quercetum ma ogromne znaczenie z punktu widzenia ochrony bioróżnorodności dla całego obszaru Wyżyny Krakowsko-Częstochowskiej, w szczególności dla Ostoi Olsztyńsko-Mirowskiej PLH 240015. Stwierdzono w nich obecność gatunku z Załącznika 2 Obwieszczenia Ministra... (2014) - Adenophora liliifolia, czterech gatunków objętych aktualnie ochroną ścisłą (Adenophora liliifolia, Bupleurum longifolium, Festuca amethystina i Lilium martagon) i 14 ochroną częściową. Sześć znalezionych gatunków umieszczonych jest na polskiej czerwonej liście roślin naczyniowych (Adenophora liliifolia, Bupleurum longifolium, Festuca amethystina, Trifolium rubens, Geranium sylvaticum i Monotropa hypophaega). Warto zwrócić uwagę na wysokie liczby gatunków: w różnym stopniu zagrożonych w województwie śląskim (67) i uznanych za bardzo rzadkie i rzadkie na Wyżynie Krakowsko-Częstochowskiej (29), z których wiele związanych jest mniej lub bardziej ściśle $\mathrm{z}$ interesującym nas typem ekosystemu.

Odnotować należy, że w trakcie badań znaleziono dwa taksony nowe dla Wyżyny Krakowsko-Częstochowskiej: Festuca amethystina i Quercus $\times$ rosacea.

Przedyskutowano niektóre problemy związane z obecnością i charakterem geograficznym Potentillo albae-Quercetum na terenie badań.

\section{LITERATURA}

Barć A., Brzeg A., Uziębło A. K., Wika S. (2015): The upland mixed fir coniferous forest Abietetum albae Dziubałtowski 1928 in the central part of the Cracow-Częstochowa Upland. Differentiation, regional specificity, structure, dynamics, and maintenance. Ss. $143+$ tab. + phot. Wyd. UŚ. Katowice.

Bąba W. (2002): Szata roślinna rezerwatu krajobrazowego „Dolina Eliaszówki”. Prądnik. Pr. Muz. Szafera, 13: 115-120.

Brzeg A., Kasprowicz M. (2001): Dąbrowy Wielkopolski ze szczególnym uwzględnieniem „Płyty Krotoszyńskiej”. [W:] Wojterska M. (red.). Szata roślinna Wielkopolski i Pojezierza Południowopomorskiego: 177-192. Przewodnik sesji terenowych 52. Zjazdu PTB, 24-28 września 2001. Bogucki Wyd. Nauk. Poznań.

Brzeg A., Kasprowicz M., Rakowski W., Wojterska M., Yakushenko D. (2009): Differentiation of thermophilous oak forest Potentillo albae-Quercetum Libb. 1933 nom. invers. in Europe. 18th I.A.V.S. Workshop for the Europaean Vegetation Survey Working Group. Abstracts: 81. Roma. 
Brzeg A., Wika S. (2007): Nowe dla Polski stanowisko borowika szatańskiego Boletus satanas Lenz. w środkowej części Wyżyny Krakowsko-Częstochowskiej. Bad. Fizjogr. nad Polską Zach., B, 56: 39-47.

Brzeg A., Wika S. (2011): Biocenotyczne i krajobrazowe znaczenie termofilnych ziołorośli z klasy Trifolio-Geranietea sanguinei Th. Müller 1962 na obszarze środkowej części Wyżyny Krakowsko-Wieluńskiej. [W:] Żurowska-Oleś E., Szczypek S., Mastaj J. (red.). XX Sympozjum Jurajskie „Człowiek i przyroda Wyżyny Krakowsko-Wieluńskiej”: 36-41. ZPK Woj. Śląskiego. Będzin.

Brzeg A., Wika S. (2014): Termofilne ziołorośla okrajkowe z klasy Trifolio-Geranietea sanguinei Th. Müller 1962 na obszarze środkowej części Wyżyny Krakowsko-Częstochowskiej. Wyd. 2 popr. Ss. 179. ZPK Woj. Śląskiego. Katowice.

Celiński F., Wika S. (1975): Zbiorowiska roślinne rezerwatu Zielona Góra koło Częstochowy. Zesz. Przyr. Opolskiego TPN, 14-15 (1974-1975): 45-63.

Celiński F., Wika S. (1978): Próba nowego spojrzenia na stosunki fitosocjologiczne rezerwatu „Parkowe” w Złotym Potoku koło Częstochowy. Fragm. Flor. Geobot., 24(2): 277-307.

Czechowski D., Król P., Skrzypiec P. (b.d.): Ostoja Olsztyńsko-Mirowska PLH 240015. http:// katowice.rdos.gov.pl (dostęp: 13.05.2017).

Dzwonko Z. (2007): Przewodnik do badań fitosocjologicznych. Ss. 304. Inst. Bot. Uniw. Jagiellońskiego, Sorus. Poznań-Kraków.

Fojcik B. (2011): Mchy Wyżyny Krakowsko-Częstochowskiej w obliczu antropogenicznych przemian szaty roślinnej. Ss. 232. Wyd. UŚ. Katowice.

Głazek T. (1973): Zespoły leśne północno-wschodniego i wschodniego przedpola Gór Świętokrzyskich. Monogr. Bot., 38: 1-158.

Hereźniak J. (1975): Nowe stanowiska Melica uniflora Retz. w zbiorowiskach leśnych północnej części Wyżyny Śląsko-Krakowskiej. Fragm. Flor. Geobot., 21(1): 17-20.

Hereźniak J. (1993): Stosunki geobotaniczno-leśne północnej części Wyżyny Śląsko-Krakowskiej na tle zróżnicowania i przemian środowiska. Monogr. Bot., 75: 1-368.

Hereźniak J. (2002): Rezerwaty przyrody ziemi częstochowskiej. Studium przyrodniczo-historyczne. Ss. 301. LOP. Częstochowa.

Hereźniak J., Krasowska H., Ławrynowicz M. (1970): Roślinność przełomu Warty pod Częstochową. Ziemia Częstochowska, 8/9: 315-350.

Jakubowska-Gabara J. (1993): Recesja zespołu świetlistej dąbrowy Potentillo albae-Quercetum Libb. 1933 w Polsce. Ss. 190. Wyd. Uniw. Łódzkiego. Łódź.

Kaźmierczakowa R. (1971): Ekologia i produkcja runa świetlistej dąbrowy w rezerwatach Kwiatówka i Lipny Dół na Wyżynie Małopolskiej. Stud. Naturae, A, 5: 1-104.

Kaźmierczakowa R., Bloch-Orłowska J., Celka Z., Cwener A., Dajdok Z., Michalska-Hejduk D., Pawlikowski P., Szczęśniak E., Ziarnek K. (2016): Polska czerwona lista paprotników i roślin kwiatowych. - Polish red list of pteridophytes and flowering plants. Ss. 44. Inst. Ochr. Przyr. PAN. Kraków.

Kondracki J. (2008): Geografia fizyczna Polski. Ss. 463. Wyd. Nauk. PWN. Warszawa.

Krotoska T. (1991): Grądy i dąbrowy okolic Konina oraz ich formy zniekształcone. [W:] Krotoska T. (red.). Zbiorowiska roślin naczyniowych Konińskiego Zagłębia Węgla Brunatnego i jego obrzeży: 165-210 + tab. PTPN, Pr. Kom. Biol., 70. PWN. Warszawa-Poznań.

Kurowski J. (1976): Charakterystyka fitosocjologiczna Lasów Grotnicko-Lućmierskich koło Łodzi. Acta Univ. Lodz., Fol. Bot., 14: 35-83.

Kurowski J. K. (1979): Bory i lasy z antropogenicznie wprowadzoną sosną w dorzeczu środkowej Pilicy i Warty. Acta Univ. Lodz., Fol. Bot., 29: 3-158.

Kurzac M. (1984): Flora uroczyska leśnego Mierzyce koło Wielunia. Acta Univ. Lodz., Fol. Bot., 3: 109-126.

Kurzac M. (1986): Flora i roślinność projektowanego rezerwatu „Dąbrowa w Niżankowicach”. Acta Univ. Lodz., Fol. Sozol., 2: 567-599. 
Kwiatkowska A. J., Wyszomirski T. (1988): Decline of Potentillo albae-Quercetum phytocoenoses associated with the invasion of Carpinus betulus. Vegetatio, 75: 49-55.

Matuszkiewicz J. M. (2005): Zespoły leśne Polski. Ss. 358. Wyd. Nauk. PWN. Warszawa.

Matuszkiewicz J. M., Kozłowska A. B. (1991): Przegląd fitosocjologiczny zbiorowisk leśnych Polski - ciepłolubne dąbrowy. Fragm. Flor. Geobot., 36(1): 203-256.

Matuszkiewicz W., Faliński J. B., Kostrowicki A. S., Matuszkiewicz J. M., Olaczek R., Wojterski T. (1995): Potencjalna roślinność naturalna Polski. - Potential natural vegetation of Poland. Mapa przeglądowa 1:300 000. Arkusz 8: Wzniesienia Południowomazowieckie i Wyżyna Środkowomałopolska. PAN, Inst. Geogr. i Przestrz. Zagosp., Wojsk. Zakł. Kartograf. Warszawa.

Matuszkiewicz W., Sikorski P., Szwed W., Danielewicz W., Kiciński P., Wierzba M. (2012): Przegląd zespołów leśnych występujących w Polsce. [W:] Matuszkiewicz W., Sikorski P., Szwed W., Wierzba M. (red.). Zbiorowiska roślinne Polski. Lasy i zarośla: 136-518. Wyd. Nauk. PWN. Warszawa.

Medwecka-Kornaś A. (1952): Zespoły leśne Jury Krakowskiej. Ochr. Przyr., 20: 133-236.

Medwecka-Kornaś A., Gawroński S. (1990): The dieback of fir Abies alba Mill. and changes in the Pino-Quercetum stands in the Ojców National Park (Southern Poland). Vegetatio, 87: $175-186$

Medwecka-Kornaś A., Kornaś J. (1963): Mapa zbiorowisk roślinnych Ojcowskiego Parku Narodowego. Ochr. Przyr., 29: 17-87 + mapa.

Michalik S. (1972): Ciepłolubne lasy bukowe na Wyżynie Krakowsko-Częstochowskiej. Fragm. Flor. Geobot., 16(2): 215-225 + tab.

Michalik S. (1980): Roślinność rzeczywista centralnej części Wyżyny Krakowskiej. - The contemporary vegetation of the central part of the Crakow Upland. Ochr. Przyr., 43: 55-74+ mapa.

Michalik S. (1981): Zespoły roślinne rezerwatu „Góra Chełm” koło Zawiercia. Stud. Ośr. Dok. Fizjogr. PAN, 8: 119-133.

Michalska-Hejduk D. (1998): Flora i roślinność rezerwatu leśnego „Kaliszak”. - Flora and vegetation of the "Kaliszak" forest reserve. Acta Univ. Lodz., Folia Bot., 12: 73-93.

Michalska-Hejduk D., Kobojek S., Hejduk J., Michalski M. (1999): Walory przyrodnicze rezerwatu „Góra Zborów” koło Kroczyc. - Nature value of the reserve "Góra Zborów” near Kroczyce. Ziemia Częstochowska, 26: 237-308.

Mirek Z., Piękoś-Mirkowa H., Zając A., Zając M. (2002): Flowering plants and pteridophytes of Poland. A checklist. - Krytyczna lista roślin naczyniowych Polski. Ss. 442. W. Szafer Inst. of Bot., Polish Acad. of Sci. Kraków.

Obwieszczenie Ministra Środowiska z dnia 30 października 2014 r. w sprawie ogłoszenia jednolitego tekstu rozporządzenia Ministra Środowiska w sprawie siedlisk przyrodniczych oraz gatunków będących przedmiotem zainteresowania Wspólnoty, a także kryteriów wyboru obszarów kwalifikujących się do uznania lub wyznaczenia jako obszary Natura 2000. Dz.U. RP z dnia 4 grudnia 2014 r. Poz. 1713.

Ochyra R., Żarnowiec J., Bednarek-Ochyra H. (2003): Census catalogue of Polish mosses. Ss. 252. W. Szafer Inst. of Bot., Polish Acad. of Sci. Kraków.

Olaczek R. (1965): Rezerwat jodłowy „Murowaniec”. Zesz. Nauk. Uniwersytetu Łódzkiego, Ser. Mat.-Przyr., 18: 113-130.

Parusel J. B., Urbisz A. (red.). (2012): Czerwona lista roślin naczyniowych województwa śląskiego. - The red list of vascular plants of Silesian voivodship. [W:] Parusel J. B. (red.). Czerwone listy wybranych grup grzybów i roślin województwa śląskiego 2: 105-177. Raporty Opinie, 6. Katowice.

Pawłowski B. (1972): Skład i budowa zbiorowisk roślinnych oraz metody ich badania. [W:] Szafer W., Zarzycki K. (red.). Szata roślinna Polski I: 237-279. PWN. Warszawa.

Ratyńska H., Wojterska M., Brzeg A., Kołacz M. (2010): Multimedialna encyklopedia zbiorowisk roślinnych Polski ver. 1.1. Uniw. Kazimierza Wielkiego, Inst. Eduk. Tech. Inf. Bydgoszcz. 
Rozporządzenie Ministra Środowiska z dnia 6 listopada 2013 r. zmieniające rozporządzenie w sprawie siedlisk przyrodniczych oraz gatunków będących przedmiotem zainteresowania Wspólnoty, a także kryteriów wyboru obszarów kwalifikujących się do uznania lub wyznaczenia jako obszary Natura 2000. Dz.U. RP z dnia 8 listopada 2013 r. Poz. 1302.

Rozporządzenie Ministra Środowiska z dnia 9 października 2014 r. w sprawie ochrony gatunkowej roślin. Dz.U. RP z dnia 16 października 2014 r. Poz. 1409.

Sokołowski M. (1928): Badania socjologiczne w rezerwacie bukowym w Złotym Potoku nad Wiercicą. Sylwan, 46: 439-480.

Stebel A., Fojcik B., Klama H., Żarnowiec J. (2012): Czerwona lista mszaków województwa śląskiego. - The red list of the threatened bryophytes of Silesian voivodship. [W:] Parusel J. B. (red.). Czerwone listy wybranych grup grzybów i roślin województwa śląskiego 2: 73-104. Raporty Opinie, 6. Katowice.

Urbisz A. (2004): Konspekt flory roślin naczyniowych Wyżyny Krakowsko-Częstochowskiej. Ss. 286. Wyd. UŚ. Katowice.

Urbisz A. (2008): Różnorodność i rozmieszczenie roślin naczyniowych jako podstawa regionalizacji geobotanicznej Wyżyny Krakowsko-Częstochowskiej. Ss. 136. Pr. Nauk. UŚ, 2630. Katowice.

Wika S. (1981): Les phytocomplexes potentiels de paysage et les paysages potentiels des végétaux du Jura de Częstochowa (Plateau de Cracovie-Wieluń, Sud Pologne). - Potencjalne fitokompleksy krajobrazowe i potencjalne krajobrazy roślinności środkowej części Wyżyny Krakowsko-Wieluńskiej. Fragm. Flor. Geobot., 27(3): 509-521 + mapa.

Wika S. (1983): Zbiorowiska borowe środkowej części Wyżyny Krakowsko-Wieluńskiej. Acta Biol. UŚ, 12(4): 49-64 + tab.

Wika S. (1986): Zagadnienia geobotaniczne środkowej części Wyżyny Krakowsko-Wieluńskiej. Ss. 156. Pr. Nauk. Uniw. Śląskiego, 815. Katowice.

Wika S. (1987): Lasy liściaste środkowej części Wyżyny Krakowsko-Wieluńskiej. Cz. I. AlnoPadion i Carpinion betuli. Bad. Fizjogr. nad Polską Zach., B, 38: 81-112.

Wika S. (1989): Lasy liściaste środkowej części Wyżyny Krakowsko-Wieluńskiej. II. Fagion syl vaticae i Calamagrostio-Quercetum petraeae. Bad. Fizjogr. nad Polską Zach., B, 39: 37-86.

Wika S., Barć A. (2011): Long-term changes and maintenance of Phyllitis scolopendrium (L.) Newman population in the Wodąca Valley (the Cracow-Częstochowa Upland). Biodiv. Res. Conserv., 23: 75-82.

Wika S., Cybulski M., Szczypek T. (2007): Association Galio odorati-Fagetum (R. Tx. 1955) Müller 1992 à la limite sud-est son aire de distribution. Doc. Phytosoc. (Camerino 2003), N.S., 20: 135-141.

Wika S., Szczypek T., Snytko W. A. (2000): Krajobrazy Doliny Wodącej na Wyżynie KrakowskoWieluńskiej. Ss. 85. ZPK Woj. Śląskiego, WBiOŚ, WNoZ UŚ. Dąbrowa Górnicza-Katowice-Sosnowiec.

Wika S., Szczypek T., Widera Z. (1984): Zbiorowiska roślinne projektowanego rezerwatu w Pazurku odniesione do rzeźby terenu i stosunków glebowych. Arch. Ochr. Środ., 2: 143-164+ tab.

Wojterska M., Brzeg A., Kasprowicz M., Rakowski W. (2007): Studia nad zróżnicowaniem regionalnym i siedliskowym świetlistej dąbrowy Potentillo albae-Quercetum Libb. 1933 nom. invers. w środkowej Europie. Z Zakł. Ekol. Rośl. i Ochr. Środ. UAM. Poznań (mskr.).

Wojterska M., Wiszniewska K. (1996): Świetlista dąbrowa Potentillo albae-Quercetum Libb. 1933 w leśnictwie Daniele koło Obrzycka na tle świetlistych dąbrów Wielkopolski. Stan zachowania i projekt ochrony. Bad. Fizjogr. nad Polską Zach., B, 45: 41-77.

Wojterska M., Wiszniewska K., Gmaj M. (2001): Roślinność rezerwatu „Świetlista dąbrowa koło Obrzycka”. [W:] Wojterska M. (red.). Szata roślinna Wielkopolski i Pojezierza Południowopomorskiego: 228-242. Przewodnik sesji terenowych 52. Zjazdu PTB, 24-28 września 2001. Bogucki Wyd. Nauk. Poznań. 


\section{THERMOPHILOUS OAK FOREST POTENTILLO ALBAE-QUERCETUM LIBBERT 1933 NOM. INVERS. IN THE CENTRAL PART OF THE KRAKÓW- -CZESTOCHOWA UPLAND}

\section{Summary}

Phytosociological research on the occurrence and differentiation of the subcontinental thermophilous oak forest Potentillo albae-Quercetum Libbert 1933 nom. invers. in the central part of the Kraków-Częstochowa Upland (South Poland) was carried out in the first ten days of August 2011. This plant association is classified as a Natura 2000 priority habitat (91I0 code). The presence of patches of it, mostly in large forest areas, was confirmed in 7 localities (Fig. 1). Within those patches 35 relevés were made. The relevés were compiled in two tables (Tab. 1 and 2) after detailed analysis of their floristic composition and comparison with materials from other areas.

The analysis showed that the investigated phytocoenoses represent the subassociation P.a.-Q. brachypodietosum pinnati. The subassociation occurring in the study area was separated into two variants: one with Pleurozium schreberi (on \pm acid and poorer sites), and one with Asarum europaeum (on richer, neutral or base-rich sites); the second variant was further differentiated into two sub-variants. It was also noted that the characteristic floristic composition of the association occurs both in nearly natural, old-growth forests, in which multigenerational stands are composed of oak (mainly Quercus petraea), and in disturbed commercially managed forests with planted Pinus sylvestris as well. In the investigated area, just as in other regions of Central Europe, the association constitutes one of the floristically richest forest ecosystems (on average, it 71 plant taxa per relevé were confirmed; in the entirety of the material, 250 taxa of vascular plants and bryophytes were listed).

The presence of patches of Potentillo albae-Quercetum is very important for the whole area of the Kraków-Częstochowa Upland (especially for the Olsztyn-Mirów Natura 2000 site PLH 240015) from the viewpoint of biodiversity protection. Within those phytocoenoses, were found localities of: Adenophora liliifolia (Natura 2000 species, mentioned in Appendage 2); 4 plant species currently protected by law (Adenophora liliifolia, Bupleurum longifolium, Festuca amethystina and Lilium martagon); and 14 taxa under partial protection as well. Six of the found species are listed on the Polish red list of vascular plants (Adenophora liliifolia, Bupleurum longifolium, Festuca amethystina, Trifolium rubens, Geranium sylvaticum, Monotropa hypophaega). Also noteworthy is the high numbers of species which are threatened in the Silesian region to varying degrees (67), and are very rare or rare in the Kraków-Częstochowa Upland (29); many of those species are more or less related to ecosystems of Potentillo albae-Quercetum. 
It needs to be emphasized that in the course of the study two species were found: Festuca amethystina and Quercus ×rosacea, which are both new for the area of the Kraków-Częstochowa Upland.

Some issues connected with the presence and the geographical distinctiveness of the Potentillo albae-Quercetum within the study area are also discussed. 